OPEN ACCESS

Edited by:

Richard Eleftherios Boyatzis, Case Western Reserve University,

United States

Reviewed by:

Leandro S. Almeida,

University of Minho, Portugal Celestino Rodríguez, Universidad de Oviedo Mieres, Spain David Álvarez-García,

Universidad de Oviedo Mieres, Spain

*Correspondence:

João Marôco

jpmaroco@ispa.pt

Specialty section:

This article was submitted to

Organizational Psychology,

a section of the journal

Frontiers in Psychology

Received: 23 February 2018

Accepted: 02 March 2018

Published: 20 March 2018

Citation:

Sinval J, Pasian S, Queirós C and Marôco J (2018) Brazil-Portugal

Transcultural Adaptation of the

UWES-9: Internal Consistency,

Dimensionality, and Measurement Invariance. Front. Psychol. 9:353. doi: 10.3389/fpsyg.2018.00353

\section{Brazil-Portugal Transcultural Adaptation of the UWES-9: Internal Consistency, Dimensionality, and Measurement Invariance}

\author{
Jorge Sinval ${ }^{1,2}$, Sonia Pasian ${ }^{1}$, Cristina Queirós ${ }^{2}$ and João Marôco ${ }^{3 *}$ \\ ${ }^{1}$ Faculty of Philosophy, Sciences and Letters of Ribeirão Preto, University of São Paulo, São Paulo, Brazil, 2 Faculty of \\ Psychology and Education Sciences, University of Porto, Porto, Portugal, ${ }^{3}$ William James Centre for Research, ISPA-Instituto \\ Universitário, Lisboa, Portugal
}

The aim of this paper is to present a revision of international versions of the Utrecht Work Engagement Scale and to describe the psychometric properties of a Portuguese version of the UWES-9 developed simultaneously for Brazil and Portugal, the validity evidence related with the internal structure, namely, Dimensionality, measurement invariance between Brazil and Portugal, and Reliability of the scores. This is the first UWES version developed simultaneously for both countries, and it is an important instrument for understanding employees' work engagement in the organizations, allowing human resources departments to better use workforces, especially when they are migrants. A total of 524 Brazilian workers and 522 Portuguese workers participated in the study. Confirmatory Factor Analysis, group comparisons, and Reliability estimates were used. The use of workers who were primarily professionals or administrative support, according to ISCO-08, reinforced the need to collect data on other professional occupations. Confirmatory factor analysis showed acceptable fit for the UWES-9 original three-factor solution, and a second-order factor structure has been proposed that presented an acceptable fit. Full-scale invariance was obtained between the Portuguese and Brazilian samples, both for the original three-factor first-order and second-order models. Data revealed that Portuguese and Brazilian workers didn't show statistically significant differences in the work engagement dimensions. This version allows for direct comparisons of means and, consequently, for performance of comparative and cross-cultural studies between these two countries.

Keywords: work engagement, Portuguese-Brazilian version, measurement invariance, reliability of the scores, validity evidence, psychometric properties

\section{INTRODUCTION}

The global economic crisis elicited important changes in the workforce (The Organisation for Economic Co-operation and Development; Pilati et al., 2015; OECD, 2016), namely workers changing their physical location in order to have a better salary or even a job. International enterprises also frequently changed their physical location to decrease taxes, for political reasons or to achieve lower labor costs. Moreover, workers' career expectations increased occupational mobility (Dunkerley, 2013). These factors contributed to a growing flow of international 
workers (Dollard et al., 2014). Due to the commonalities in language and cultural values, Brazilians are the majority of foreign workers in Portugal, and vice-versa (INE, 2014). In 2014, Portuguese workers represented 1\% of European labor inflows while Brazilians represented 1.1\% (OECD, 2016). The Brazilian migrants dominate the inflow entries to Portugal at $21 \%$ (Serviço de Estrangeiros e Fronteiras, 2016). Reciprocal migrant flows created new challenges to enterprises' functioning and in research about occupational health, cross-cultural studies and bias in personality assessment (van de Vijver, 2000; Hofstede et al., 2010). Moreover, Occupational Health departments are continuously alert for the psychosocial risks at work and workers' well-being, referring to positive mental health as a promoter of active and healthy aging (Direção-Geral da saúde, 2013; European Agency for Safety Health at Work, 2016).

Simultaneously, psychology reinforces the need to research new challenges instead of negative topics and to valorize wellbeing at work (Scorsolini-Comin et al., 2013; van Veldhoven and Peccei, 2015; Mäkikangas et al., 2016) or positive states such as engagement within Positive Occupational Psychology (Bakker et al., 2008, 2012; Byrne, 2014; Truss et al., 2014; Chambel, 2016; Salanova et al., 2016). Since engaged workers seem to be more energetic, enthusiastic regarding their work and have greater initiative, innovativeness and well-being (Alfes et al., 2013; Shuck et al., 2014; Bal and De Lange, 2015; de Camargo et al., 2015; Sattar et al., 2015; Graffigna, 2017; Presbitero, 2017), it is well documented that regarding human resources, work engagement plays a mediating role between organizations' human resources management practices and workers' job satisfaction, performance outcomes, team cohesion, reduced turnover or reduced job stress.

Work engagement can be defined as a positive motivational construct characterized by vigor, dedication, and absorption and, within workplaces' psychology, it is generally seen as a protector against burnout (Schaufeli and Salanova, 2007; Schaufeli and Bakker, 2010). Vigor refers to high levels of persistence, energy, and mental resilience while working, and the willingness to invest effort in one's work. Dedication is characterized by being strongly involved in one's work and experiencing a sense of meaning, enthusiasm, inspiration, and pride. Finally, absorption refers to being completely concentrated and happily immersed in one's work, with distortion of time and intrinsic enjoyment (Schaufeli et al., 2002b). Globally, work engagement is referred to a cognitive-affective persistent state in time, which is not focused on an object or a specific behavior (Salanova et al., 2000; Schaufeli, 2017). It is related to performance (Pittenger, 2015; Knight et al., 2017; Reijseger et al., 2017) and to economy, governance, and culture (Schaufeli, 2017). A recent report presented by Schaufeli (2017) analyses data from 43,850 employees from thirty-five European countries, from the "6th European Working Conditions Survey-2015," aiming to identify the relationships between work engagement at the country level and several national economic, governance and cultural indicators. The author concludes that the most engaged countries are in Northwestern Europe, whereas the least engaged are located in Southern Europe or the Balkans, with Portugal being under the European average (3.69 vs. 3.94 on a $1-5$ scale).
The most disseminated instrument to measure work engagement is the Utrecht Work Engagement Scale-UWES (Mäkikangas et al., 2016; Knight et al., 2017), created by Schaufeli and Bakker (2003). Its properties need to be investigated, to use it with more rigor. This paper aims to present a revision of international versions of the Utrecht Work Engagement Scale and to describe psychometric properties of a Portuguese version of the UWES-9 developed simultaneously for Brazil and Portugal. The UWES has a version with 17 items, distributed among three dimensions as follows: vigor (6 items), dedication (5 items), and absorption (6 items). Despite a very recent and ultra-short measure of work engagement with 3 items (Schaufeli et al., 2017), a short version is frequently used having 9 items (UWES-9), 3 for each dimension, and is recommended by some authors over the longer version (Nerstad et al., 2010; Hernandez-Vargas et al., 2016), in order to improve data quality, with advantages such as the potential decrease of missing values, the shorter amount of time to complete the questionnaire, and the increased likelihood of completing the questionnaire (Kruyen et al., 2013). This short version produced data with good psychometric properties when it was developed in the original sample (Schaufeli et al., 2006), but also in other recent independent studies (de Bruin and Henn, 2013; Littman-Ovadia and Balducci, 2013; Panthee et al., 2014; Fong and Ho, 2015; Vazquez et al., 2015). The internal consistency (Cronbach's Alpha) usually shows acceptable values (Fong and Ng, 2012) and, although is common to find high inter-factor correlations between the three dimensions, the factorial invariance of the UWES across countries has been demonstrated in student samples (Schaufeli et al., 2002a). Balducci et al. (2010) used a sample of Italian and Dutch workers, where they applied each country's version, instead of the same transcultural version, due to language specificities. Also in Greek and Dutch employees, measurement invariance was obtained using each national language (Xanthopoulou et al., 2012). Schaufeli et al. (2006) selected items through an iterative process from the original scale to rebuild the UWES-9 and obtained a version with good psychometric proprieties, namely Cronbach's $\alpha$ higher than 0.80 and a three-factor solution that fit the data better than a one-factor solution.

Being a recent and positive occupational measure, and due to its ease of use, the UWES has been translated into many languages (Schaufeli and Bakker, 2010), such as Serbian (Petrović et al., 2017), Spanish (Schaufeli et al., 2002a; Hernandez-Vargas et al., 2016), Hebrew (Littman-Ovadia and Balducci, 2013), Chinese (Fong and Ng, 2012), Norwegian (Nerstad et al., 2010), Italian (Balducci et al., 2010), Japanese (Shimazu et al., 2008), and Portuguese (Schaufeli and Bakker, 2003; Vazquez et al., 2015), showing the robustness and relevance of the three-dimensional construct of work engagement among different cultures. Despite the recent literature review of Kulikowski (2017a), in Table $\mathbf{1}$ we present a revision of some adapted versions based on the UWES-17 version or on reduced versions, using as criteria the UWES' application to workers in different countries, as well psychometric properties, considering not only confirmatory analysis referred by Kulikowski but also Exploratory Factor 
TABLE 1 | UWES versions and its Goodness-of-fit details.

\begin{tabular}{|c|c|c|c|c|c|c|c|c|c|c|}
\hline Country (Authors) & Occupational group & $N$ & Items version (factors) & Total $\alpha$ & $\chi^{2} / d f$ & TLI/NNFI & GFI & CFI & RMSEA & SRMR \\
\hline \multirow[t]{3}{*}{ Portugal (Sinval et al., 2018) } & Rescue Workers & 3,887 & CFA 17 (three) & 0.96 & 27.30 & 0.993 & - & 0.994 & 0.091 & - \\
\hline & & & CFA 9 (three) & 0.95 & 40.91 & 0.995 & - & 0.997 & 0.105 & - \\
\hline & & & CFA 9 (2nd order-three) & & 20.76 & 0.997 & - & 0.998 & 0.074 & - \\
\hline \multirow{3}{*}{$\begin{array}{l}\text { India } \\
\text { Thailand } \\
\text { (Chaudhary et al., 2018) }\end{array}$} & Information Technology & 100 & PCA 17 (one) & 0.93 & - & - & - & - & - & - \\
\hline & & 100 & & 0.92 & - & - & - & - & - & - \\
\hline & & $(200)$ & & 0.93 & - & - & - & - & - & - \\
\hline \multirow[t]{2}{*}{ Belgium } & Various & 5,062 & CFA 3 (one) & 0.85 & - & - & - & - & - & - \\
\hline & & & CFA 9 (three) & 0.93 & - & - & - & - & - & - \\
\hline \multirow[t]{2}{*}{ Finland } & & 22,117 & CFA 3 (one) & 0.80 & - & - & - & - & - & - \\
\hline & & & CFA 9 (three) & 0.94 & - & - & - & - & - & - \\
\hline \multirow[t]{2}{*}{ Japan } & & 1,968 & CFA 3 (one) & 0.85 & - & - & - & - & - & - \\
\hline & & & CFA 9 (three) & 0.95 & - & - & - & - & - & - \\
\hline \multirow[t]{2}{*}{ Netherlands } & & 38,278 & CFA 3 (one) & 0.82 & - & - & - & - & - & - \\
\hline & & & CFA 9 (three) & 0.94 & - & - & - & - & - & - \\
\hline \multirow[t]{2}{*}{ Spain } & & 10,040 & CFA 3 (one) & 0.77 & - & - & - & - & - & - \\
\hline & & & CFA 9 (three) & 0.90 & - & - & - & - & - & - \\
\hline \multicolumn{2}{|l|}{ (Schaufeli et al., 2017) } & $(77,465)$ & - & - & - & - & - & - & - & - \\
\hline \multirow[t]{6}{*}{ India (Lathabhavan et al., 2017) } & Bank & 467 & CFA 17 (one) & - & 7.48 & 0.86 & 0.82 & 0.91 & 0.13 & 0.12 \\
\hline & & & CFA 17 (three) & & 6.07 & 0.92 & 0.83 & 0.93 & 0.10 & 0.03 \\
\hline & & & CFA 15 (one) & - & 6.83 & 0.77 & 0.86 & 0.93 & 0.10 & 0.11 \\
\hline & & & CFA 15 (three) & & 5.67 & 0.83 & 0.88 & 0.94 & 0.10 & 0.03 \\
\hline & & & CFA 9 (one) & - & 5.38 & 0.87 & 0.94 & 0.96 & 0.10 & 0.10 \\
\hline & & & CFA 9 (three) & & 1.91 & 0.96 & 0.98 & 0.99 & 0.04 & 0.03 \\
\hline Iran (Torabinia et al., 2017) & Nurses & 282 & EFA 17 (three) & 0.84 & - & - & - & - & - & - \\
\hline Malaysia (Yew et al., 2017) & Primary School Teachers & 345 & CFA 17 (three) & - & - & 0.921 & - & 0.933 & 0.084 & 0.032 \\
\hline \multirow[t]{11}{*}{ Poland (Kulikowski, 2017b) } & Various & 1,420 & CFA 17 (three) & - & 21.53 & - & - & 0.84 & 0.12 & - \\
\hline & & & CFA 17 (two) & & 22.56 & - & - & 0.83 & 0.12 & - \\
\hline & & & CFA 17 (one) & & 25.37 & - & - & 0.82 & 0.13 & - \\
\hline & & & CFA 15 (three) & - & 21.75 & - & - & 0.85 & 0.12 & - \\
\hline & & & CFA 15 (two) & & 23.65 & - & - & 0.84 & 0.13 & - \\
\hline & & & CFA 15 (one) & & 25.23 & - & - & 0.82 & 0.13 & - \\
\hline & & & CFA 9 (three) & 0.90 & 20.72 & - & - & 0.94 & 0.12 & - \\
\hline & & & CFA 9 (two) & & 32.68 & - & - & 0.89 & 0.15 & - \\
\hline & & & CFA 9 (one) & & 33.60 & - & - & 0.88 & 0.15 & - \\
\hline & & & CFA 6 (two) & 0.87 & 15.78 & - & - & 0.97 & 0.10 & - \\
\hline & & & CFA 6 (one) & & 35.44 & - & - & 0.93 & 0.16 & - \\
\hline \multirow[t]{2}{*}{ Russia (Lovakov et al., 2017) } & Energy & 1,783 & CFA 9 (one) & - & 23.35 & 0.87 & - & 0.90 & 0.11 & 0.05 \\
\hline & & & CFA 9 (three) & - & 25.70 & 0.85 & - & 0.90 & 0.12 & 0.05 \\
\hline \multirow[t]{6}{*}{ Serbia (Petrović et al., 2017) } & Various & 860 & EFA 17 (three) & 0.92 & - & - & - & - & - & - \\
\hline & & & CFA 17 (one) & & 3.91 & - & 0.920 & 0.695 & 0.062 & 0.079 \\
\hline & & & CFA 17 (three) & & 3.63 & - & 0.928 & 0.732 & 0.056 & 0.077 \\
\hline & & & CFA 17 (three - from EFA) & & 3.58 & - & 0.929 & 0.736 & 0.055 & 0.070 \\
\hline & & & CFA 9 (one) & 0.90 & 5.37 & - & 0.951 & 0.832 & 0.072 & 0.083 \\
\hline & & & CFA 9 (three) & & 4.86 & - & 0.960 & 0.868 & 0.067 & 0.100 \\
\hline \multirow{5}{*}{$\begin{array}{l}\text { Sierra Leone (Vallières et al., } \\
\text { 2017) }\end{array}$} & Community Health & 334 & CFA 17 (one) & - & 2.23 & 0.689 & - & 0.728 & 0.062 & 0.069 \\
\hline & Workers & & CFA 17 (bi-factor) & & 1.92 & 0.767 & - & 0.825 & 0.054 & 0.057 \\
\hline & & & CFA 9 (one) & - & 1.82 & 0.882 & - & 0.911 & 0.050 & 0.050 \\
\hline & & & CFA 9 (three) & & 2.01 & 0.854 & - & 0.902 & 0.056 & 0.056 \\
\hline & & & CFA 9 (bi-factor) & & 2.14 & 0.844 & - & 0.921 & 0.059 & 0.059 \\
\hline \multirow[t]{7}{*}{ South Korea (Ho Kim et al., 2017) } & White-collar & 307 & EFA 9 (one) & - & 29.58 & 0.577 & - & 0.683 & 0.239 & 0.154 \\
\hline & & & EFA 9 (two - VI, DE+AB) & & 6.8 & 0.860 & - & 0.926 & 0.137 & 0.029 \\
\hline & & & EFA 9 (three) & & 2.9 & 0.954 & - & 0.985 & 0.079 & 0.013 \\
\hline & & 342 & CFA 9 (one) & - & 13.93 & 0.770 & - & 0.827 & 0.194 & 0.053 \\
\hline & & & CFA 9 (two - VI, DE+AB) & & 6.99 & 0.893 & - & 0.923 & 0.132 & 0.044 \\
\hline & & & CFA 9 (three) & & 3.86 & 0.949 & - & 0.966 & 0.091 & 0.035 \\
\hline & & $(649)$ & - & - & - & - & - & - & - & - \\
\hline
\end{tabular}


TABLE 1 | Continued

\begin{tabular}{|c|c|c|c|c|c|c|c|c|c|c|}
\hline Country (Authors) & Occupational group & $N$ & Items version (factors) & Total $\alpha$ & $\chi^{2} / d f$ & TLI/NNFI & GFI & CFI & RMSEA & SRMR \\
\hline \multirow[t]{2}{*}{ Germany } & $\begin{array}{l}\text { German workers in } \\
\text { Germany }\end{array}$ & 1,406 & \multirow[t]{4}{*}{4 (one) } & 0.89 & - & - & - & - & - & - \\
\hline & $\begin{array}{l}\text { Turkish workers in } \\
\text { Germany }\end{array}$ & 201 & & 0.90 & - & - & - & - & - & - \\
\hline Turkey & Turkish workers in Turkey & 362 & & 0.89 & - & - & - & - & - & - \\
\hline (Ulusoy et al., 2016) & (Multi-occupational) & $(1,969)$ & & 0.89 & - & - & - & - & - & - \\
\hline $\begin{array}{l}\text { Malaysia (Sulaiman and Zahoni, } \\
\text { 2016) }\end{array}$ & Salespersons & 205 & EFA 14 (two) & 0.51 & - & - & - & - & - & - \\
\hline \multirow{4}{*}{$\begin{array}{l}\text { México (Hernandez-Vargas et al., } \\
\text { 2016) }\end{array}$} & \multirow[t]{4}{*}{ Health } & \multirow[t]{4}{*}{475} & CFA 15 (one) & \multirow[t]{2}{*}{-} & 5.19 & 0.66 & - & 0.71 & 0.09 & - \\
\hline & & & CFA 15 (three) & & 2.53 & 0.88 & - & 0.90 & 0.05 & - \\
\hline & & & CFA 9 (one) & \multirow[t]{2}{*}{-} & 8.50 & 0.64 & - & 0.93 & 0.13 & - \\
\hline & & & CFA 9 (three) & & 1.70 & 0.97 & - & 0.98 & 0.04 & - \\
\hline Saudi Arabia (Eman-Nafa, 2016) & Primary School Teachers & 414 & 9 (three) & 0.85 & - & - & - & - & - & - \\
\hline \multirow[t]{4}{*}{ Switzerland (Zecca et al., 2015) } & \multirow[t]{4}{*}{ Multi-occupational } & \multirow[t]{4}{*}{661} & CFA 17 (one) & \multirow[t]{2}{*}{0.93} & 4.04 & 0.80 & - & 0.82 & 0.12 & 0.07 \\
\hline & & & CFA 17 (three) & & 3.05 & 0.86 & - & 0.88 & 0.10 & 0.08 \\
\hline & & & CFA 9 (one) & \multirow[t]{2}{*}{0.92} & 21.33 & 0.82 & - & 0.87 & 0.18 & 0.06 \\
\hline & & & CFA 9 (three) & & 15.44 & 0.89 & - & 0.93 & 0.14 & 0.08 \\
\hline $\begin{array}{l}\text { United States of America } \\
\text { (Matz-Costa, 2016) }\end{array}$ & Various & 2,195 & 9 (three) & 0.91 & - & - & - & - & - & - \\
\hline \multirow[t]{6}{*}{ Peru (Flores Jiménez et al., 2015) } & \multirow[t]{6}{*}{ Teachers } & \multirow[t]{6}{*}{145} & CFA 15 (one) & \multirow[t]{3}{*}{-} & 2.65 & - & - & 0.871 & 0.107 & 0.105 \\
\hline & & & CFA 15 (two) & & 2.16 & - & - & 0.911 & 0.090 & 0.085 \\
\hline & & & CFA 15 (three) & & 1.96 & - & - & 0.928 & 0.082 & 0.073 \\
\hline & & & CFA 9 (one) & \multirow[t]{3}{*}{-} & 1.88 & - & - & 0.956 & 0.078 & 0.092 \\
\hline & & & CFA 9 (two) & & 1.12 & - & - & 0.999 & 0.029 & 0.064 \\
\hline & & & CFA 9 (three) & & 0.76 & - & - & 1.000 & 0.000 & 0.042 \\
\hline \multirow[t]{4}{*}{ Brazil (Vazquez et al., 2015) } & \multirow[t]{4}{*}{ Various } & 1,167 & CFA 17 (one) & 0.95 & 15.16 & 0.95 & - & 0.96 & 0.10 & - \\
\hline & & & CFA 17 (three) & & 13.67 & 0.95 & - & 0.96 & 0.10 & - \\
\hline & & & CFA 9 (one) & 0.94 & 10.05 & 0.97 & - & 0.98 & 0.13 & - \\
\hline & & & CFA 9 (three) & & 7.16 & 0.98 & - & 0.98 & 0.12 & - \\
\hline Germany (Sautier et al., 2015) & Patients with & 179 & CFA 9 (one) & 0.94 & 5.48 & 0.88 & 0.85 & 0.91 & 0.16 & - \\
\hline & $\begin{array}{l}\text { hematological } \\
\text { malignancies }\end{array}$ & & CFA 9 (three) & & 5.82 & 0.87 & 0.86 & 0.91 & 0.17 & - \\
\hline China (Fong and $\mathrm{Ho}, 2015$ ) & Health & 1,112 & CFA 9 (one) & - & 4.88 & - & - & 0.903 & 0.084 & - \\
\hline & & & CFA 9 (three) & & 3.12 & - & - & 0.936 & 0.072 & - \\
\hline & & & CFA 9 (partial bi-factor) & & 2.59 & - & - & 0.941 & 0.074 & - \\
\hline & & & BCFA 9 (one) & & - & - & - & - & - & - \\
\hline & & & BCFA 9 (three) & & - & - & - & - & - & - \\
\hline & & & BCFA 9 (partial bi-factor) & & - & - & - & - & - & - \\
\hline Italy (Villotti et al., 2014) & Mental ill workers & 310 & CFA 9 (one) & 0.94 & 5.45 & 0.956 & - & 0.967 & 0.132 & - \\
\hline & & & CFA 9 (three) & & 3.15 & 0.979 & - & 0.986 & 0.092 & - \\
\hline Mexico (Villavicencio-Ayub et al., & Various & 120 & EFA 17 (three) & 0.90 & - & - & - & - & - & - \\
\hline 2014) & & 904 & CFA 17 (three from EFA) & & 5.42 & 0.96 & - & 0.97 & 0.07 & - \\
\hline & & $(1024)$ & - & - & - & - & - & - & - & - \\
\hline Nepal (Panthee et al., 2014) & Nurses & 438 & CFA 17 (one) & 0.72 & 3.72 & 0.86 & 0.88 & 0.88 & 0.07 & - \\
\hline & & & CFA 17 (three) & & 3.43 & 0.87 & 0.89 & 0.89 & 0.07 & - \\
\hline & & & CFA 9 (one) & 0.76 & 5.35 & 0.89 & 0.92 & 0.92 & 0.10 & - \\
\hline & & & CFA 9 (two) & & 4.50 & 0.91 & 0.94 & 0.93 & 0.08 & - \\
\hline & & & CFA 9 (three) & & 3.75 & 0.93 & 0.95 & 0.95 & 0.07 & - \\
\hline Puerto Rico & Various & 2,796 & CFA 9 (one) & 0.92 & 25.82 & 0.91 & - & 0.92 & - & 0.04 \\
\hline (Rodríguez-Montalbán et al., 2014) & & & CFA 9 (three) & & 19.46 & 0.93 & - & 0.95 & - & 0.03 \\
\hline Pakistan (Yusoff et al., 2013) & Academic staff & 400 & CFA 9 (one) & 0.87 & 5.57 & - & 0.69 & 0.78 & 0.126 & - \\
\hline & & & CFA 9 (two) & & 4.96 & - & 0.78 & 0.88 & 0.164 & - \\
\hline & & & CFA 9 (three) & & 2.81 & - & 0.98 & 0.99 & 0.064 & - \\
\hline
\end{tabular}


TABLE 1 | Continued

\begin{tabular}{|c|c|c|c|c|c|c|c|c|c|c|}
\hline Country (Authors) & Occupational group & $N$ & Items version (factors) & Total $\alpha$ & $\chi^{2} / d f$ & TLI/NNFI & GFI & CFI & RMSEA & SRMR \\
\hline \multirow[t]{4}{*}{ Italy (Simbula et al., 2013) } & Teachers & 488 & CFA 17 (one) & - & 6.77 & 0.84 & 0.82 & 0.86 & 0.11 & - \\
\hline & & & CFA 17 (three) & & 5.76 & 0.87 & 0.84 & 0.89 & 0.10 & - \\
\hline & & & CFA 9 (one) & - & 9.16 & 0.89 & 0.89 & 0.91 & 0.13 & - \\
\hline & & & CFA 9 (three) & & 7.45 & 0.91 & 0.92 & 0.94 & 0.11 & - \\
\hline \multirow{2}{*}{$\begin{array}{l}\text { Israel (Littman-Ovadia and } \\
\text { Balducci, 2013) }\end{array}$} & White-collar & 252 & CFA 9 (one) & 0.93 & 4.23 & - & - & 0.98 & 0.11 & 0.04 \\
\hline & & & CFA 9 (three) & & 2.81 & - & - & 0.99 & 0.08 & 0.04 \\
\hline Chile (Gilchrist et al., 2013) & Health & 165 & EFA 17 (two) & 0.87 & - & - & - & - & - & - \\
\hline \multirow{3}{*}{$\begin{array}{l}\text { South Africa (de Bruin and Henn, } \\
\text { 2013) }\end{array}$} & Various & 369 & CFA 9 (one) & - & 6.95 & 0.958 & - & 0.943 & 0.128 & - \\
\hline & & & CFA 9 (three) & & 5.12 & 0.974 & - & 0.961 & 0.107 & - \\
\hline & & & CFA 9 (partial bi-factor) & & 1.69 & 0.996 & - & 0.993 & 0.044 & - \\
\hline \multirow[t]{3}{*}{ India (Alok, 2013) } & Professionals & 182 & CFA 9 (one) & 0.85 & 3.40 & - & - & 0.893 & 0.115 & 0.063 \\
\hline & & & CFA 9 (two) & & 3.52 & - & - & 0.892 & 0.118 & 0.063 \\
\hline & & & CFA 9 (2nd order - two) & & 3.52 & - & - & 0.892 & 0.118 & 0.063 \\
\hline \multirow{13}{*}{$\begin{array}{l}\text { United States of America (Mills } \\
\text { et al., 2012) }\end{array}$} & County extension agents & 98 & CFA 17 (one) & 0.91 & 2.18 & - & - & 0.83 & 0.11 & - \\
\hline & & & $\begin{array}{l}\text { CFA } 17 \text { (two - DE, Vl } \\
+ \text { AB) }\end{array}$ & & 2.14 & - & - & 0.83 & 0.11 & - \\
\hline & & & CFA 17 (three) & & 2.98 & - & - & 0.71 & 0.11 & - \\
\hline & & & CFA 9 (one) & 0.90 & 2.41 & - & - & 0.92 & 0.12 & - \\
\hline & & & CFA 9 (two - DE, VI +AB) & & 2.29 & - & - & 0.93 & 0.12 & - \\
\hline & & & CFA 9 (three) & & 1.93 & - & - & 0.95 & 0.10 & - \\
\hline & Various & 120 & CFA 17 (one) & 0.89 & 2.50 & - & - & 0.81 & 0.11 & - \\
\hline & & & $\begin{array}{l}\text { CFA } 17 \text { (two - DE, VI } \\
+A B)\end{array}$ & & 2.48 & - & - & 0.81 & 0.11 & - \\
\hline & & & CFA 17 (three) & & 2.47 & - & - & 0.81 & 0.11 & - \\
\hline & & & CFA 9 (one) & 0.84 & 2.07 & - & - & 0.94 & 0.09 & - \\
\hline & & & CFA 9 (two - DE, VI +AB) & & 2.57 & - & - & 0.91 & 0.11 & - \\
\hline & & & CFA 9 (three) & & 2.74 & - & - & 0.90 & 0.12 & - \\
\hline & & (218) & - & - & - & - & - & - & - & - \\
\hline \multirow{2}{*}{$\begin{array}{l}\text { United States of America (Wefald } \\
\text { et al., 2012) }\end{array}$} & Financial & 382 & CFA 9 (one) & 0.93 & 12.65 & - & 0.83 & 0.87 & 0.18 & - \\
\hline & & & CFA 9 (three) & & 10.42 & - & 0.88 & 0.91 & 0.16 & - \\
\hline $\begin{array}{l}\text { New Zealand (Viljevac et al., } \\
\text { 2012) }\end{array}$ & Call centers & 139 & CFA 17 (three) & - & 1.95 & 0.878 & - & 0.905 & 0.083 & - \\
\hline \multirow[t]{6}{*}{ Hong Kong (Fong and Ng, 2012) } & Elderly service & 992 & CFA 17 (one) & - & 7.66 & 0.80 & - & 0.83 & 0.08 & 0.07 \\
\hline & & & CFA 17 (three) & & 7.37 & 0.81 & - & 0.84 & 0.08 & 0.07 \\
\hline & & & CFA 15 (one) & - & 7.96 & 0.81 & - & 0.84 & 0.08 & 0.07 \\
\hline & & & CFA 15 (three) & & 8.05 & 0.81 & - & 0.84 & 0.09 & 0.07 \\
\hline & & & CFA 9 (one) & 0.88 & 8.51 & 0.87 & - & 0.90 & 0.09 & 0.05 \\
\hline & & & CFA 9 (three) & & 7.18 & 0.90 & - & 0.93 & 0.08 & 0.05 \\
\hline \multirow[t]{5}{*}{ Greece } & Various & 206 & CFA 15 (one) & - & 3.71 & - & 0.80 & 0.89 & 0.12 & 0.05 \\
\hline & & & $\begin{array}{l}\text { CFA } 15 \text { (two - Vl, } \\
\text { DE+AB) }\end{array}$ & & 3.52 & - & 0.82 & 0.90 & 0.11 & 0.05 \\
\hline & & & $\begin{array}{l}\text { CFA } 15 \text { (two - DE, } \\
\text { VI+AB) }\end{array}$ & & 3.55 & - & 0.83 & 0.90 & 0.11 & 0.05 \\
\hline & & & $\begin{array}{l}\text { CFA } 15 \text { (two - AB, } \\
\text { VI+DE) }\end{array}$ & & 3.72 & - & 0.80 & 0.89 & 0.12 & 0.05 \\
\hline & & & CFA 15 (three) & & 3.43 & - & 0.83 & 0.91 & 0.11 & 0.05 \\
\hline \multirow[t]{5}{*}{ Netherlands } & & 162 & CFA 15 (one) & - & 3.34 & - & 0.79 & 0.88 & 0.12 & 0.06 \\
\hline & & & $\begin{array}{l}\text { CFA } 15 \text { (two - Vl, } \\
\text { DE+AB) }\end{array}$ & & 3.12 & - & 0.80 & 0.89 & 0.12 & 0.07 \\
\hline & & & $\begin{array}{l}\text { CFA } 15 \text { (two - DE, } \\
\text { VI+AB) }\end{array}$ & & 2.97 & - & 0.81 & 0.90 & 0.11 & 0.06 \\
\hline & & & $\begin{array}{l}\text { CFA } 15 \text { (two - AB, } \\
\text { VI+DE) }\end{array}$ & & 3.24 & - & 0.80 & 0.88 & 0.12 & 0.06 \\
\hline & & & CFA 15 (three) & & 2.93 & - & 0.82 & 0.90 & 0.11 & 0.06 \\
\hline (Xanthopoulou et al., 2012) & & $(368)$ & MGCFA 15 (three) & - & 3.18 & - & - & 0.90 & 0.08 & 0.05 \\
\hline \multirow[t]{5}{*}{ Argentina (Spontón et al., 2012) } & Various & 337 & EFA 16 (two) & 0.89 & - & - & - & - & - & - \\
\hline & & 337 & CFA 17 (one) & 0.90 & 3.17 & 0.88 & 0.88 & 0.89 & 0.081 & - \\
\hline & & & CFA 17 (three) & & 2.93 & 0.89 & 0.89 & 0.91 & 0.077 & - \\
\hline & & & CFA 16 (two - from EFA) & 0.89 & 2.93 & 0.90 & 0.89 & 0.91 & 0.077 & - \\
\hline & & $(674)$ & - & - & - & - & - & - & - & - \\
\hline
\end{tabular}


TABLE 1 | Continued

\begin{tabular}{|c|c|c|c|c|c|c|c|c|c|c|}
\hline Country (Authors) & Occupational group & $N$ & Items version (factors) & Total $\alpha$ & $\chi^{2} / d f$ & TLI/NNFI & GFI & CFI & RMSEA & SRMR \\
\hline \multirow[t]{2}{*}{ Australia } & Teachers & 208 & CFA 9 (one) & 0.93 & 8.77 & - & - & 0.86 & 0.19 & - \\
\hline & & & CFA 9 (three) & & 6.96 & - & - & 0.90 & 0.17 & - \\
\hline \multirow[t]{2}{*}{ Canada } & & 256 & CFA 9 (one) & 0.88 & 9.47 & - & - & 0.80 & 0.18 & - \\
\hline & & & CFA 9 (three) & & 5.04 & - & - & 0.92 & 0.13 & - \\
\hline \multirow[t]{2}{*}{ Hong Kong } & & 100 & CFA 9 (one) & 0.93 & 4.05 & - & - & 0.88 & 0.18 & - \\
\hline & & & CFA 9 (three) & & 2.58 & - & - & 0.95 & 0.13 & - \\
\hline \multirow[t]{2}{*}{ Indonesia } & & 100 & CFA 9 (one) & 0.81 & 2.79 & - & - & 0.86 & 0.13 & - \\
\hline & & & CFA 9 (three) & & 2.97 & - & - & 0.87 & 0.14 & - \\
\hline \multirow[t]{2}{*}{ Oman } & & 192 & CFA 9 (one) & 0.90 & 5.91 & - & - & 0.86 & 0.16 & - \\
\hline & & & CFA 9 (three) & & 4.72 & - & - & 0.91 & 0.14 & - \\
\hline (Klassen et al., 2012) & & (856) & CFA 9 (one) & 0.93 & 8.77 & - & - & 0.86 & 0.19 & - \\
\hline \multirow[t]{4}{*}{ India (Chaudhary et al., 2012) } & Manufacturing and & 438 & CFA 17 (one) & 0.90 & 2.59 & 0.905 & 0.921 & 0.917 & 0.060 & - \\
\hline & Services & & CFA 17 (three) & & 2.30 & 0.922 & 0.933 & 0.933 & 0.055 & - \\
\hline & & & CFA 9 (one) & 0.82 & 2.34 & 0.962 & 0.970 & 0.962 & 0.055 & - \\
\hline & & & CFA 9 (three) & & 2.42 & 0.964 & 0.972 & 0.964 & 0.057 & - \\
\hline \multirow{2}{*}{$\begin{array}{l}\text { Netherlands (Breevaart et al., } \\
\text { 2012) }\end{array}$} & Various & 271 & MGCFA 9 (one) & - & 14.66 & - & - & 0.90 & 0.10 & 0.05 \\
\hline & & & MGCFA 9 (three) & & 6.61 & - & - & 0.96 & 0.06 & 0.04 \\
\hline \multirow[t]{3}{*}{ Italy } & White-collar & 668 & CFA 9 (one) & - & 21.71 & 0.710 & 0.760 & 0.780 & 0.230 & - \\
\hline & & & CFA 9 (three) & & 7.20 & 0.894 & 0.898 & 0.929 & 0.137 & - \\
\hline & & & CFA 9 (three - Mod.) & & 2.93 & 0.967 & 0.961 & 0.982 & 0.077 & - \\
\hline \multirow[t]{3}{*}{ Netherlands } & & 2,213 & CFA 9 (one) & - & 14.81 & 0.913 & 0.916 & 0.935 & 0.112 & - \\
\hline & & & CFA 9 (three) & & 8.96 & 0.950 & 0.959 & 0.967 & 0.085 & - \\
\hline & & & CFA 9 (three - Mod.) & & 7.97 & 0.956 & 0.967 & 0.973 & 0.080 & - \\
\hline (Balducci et al., 2010) & & $(2,881)$ & MGCFA 9 (three) & 0.92 & 5.57 & 0.958 & 0.965 & 0.975 & 0.057 & - \\
\hline \multirow[t]{6}{*}{ Norway (Nerstad et al., 2010) } & Various & 1,266 & CFA 17 (one) & - & 17.52 & - & - & 0.96 & 0.11 & - \\
\hline & & & CFA 17 (two) & & 13.04 & - & - & 0.97 & 0.10 & - \\
\hline & & & CFA 17 (three) & & 12.26 & - & - & 0.97 & 0.09 & - \\
\hline & & & CFA 9 (one) & - & 24.91 & - & - & 0.95 & 0.14 & - \\
\hline & & & CFA 9 (two) & & 7.01 & - & - & 0.99 & 0.07 & - \\
\hline & & & CFA 9 (three) & & 7.43 & - & - & 0.99 & 0.07 & - \\
\hline \multirow[t]{2}{*}{ Finland (Seppälä et al., 2009) } & Various & 9,404 & CFA 17 (three) & - & 7.83 & 0.95 & - & 0.96 & 0.064 & - \\
\hline & & & CFA 9 (three) & - & 11.07 & 0.96 & - & 0.98 & 0.076 & - \\
\hline \multirow[t]{3}{*}{ USA (Muilenburg-Trevino, 2009) } & Non-profit Organization & 227 & EFA 15 (one) & 0.94 & - & - & - & - & - & - \\
\hline & Employees & & CFA 17 (one) & 0.93 & 5.04 & - & 0.74 & 0.94 & 0.14 & - \\
\hline & & & CFA 17 (three) & & 3.36 & - & 0.82 & 0.96 & 0.11 & - \\
\hline \multirow[t]{2}{*}{ Japan (Shimazu et al., 2008) } & Engineers and Nurses & 2,334 & CFA 17 (one) & - & 30.52 & - & 0.81 & 0.85 & 0.11 & - \\
\hline & & & CFA 9 (one) & 0.92 & 12.86 & - & 0.90 & 0.92 & 0.07 & - \\
\hline Australia & Various & 473 & - & - & - & - & - & - & - & - \\
\hline Belgium & & 767 & - & - & - & - & - & - & - & - \\
\hline Canada & & 267 & - & - & - & - & - & - & - & - \\
\hline Finland & & 3,651 & - & - & - & - & - & - & - & - \\
\hline France & & 221 & - & - & - & - & - & - & - & - \\
\hline Germany & & 465 & - & - & - & - & - & - & - & - \\
\hline Netherlands & & 2,163 & - & - & - & - & - & - & - & - \\
\hline Norway & & 2,114 & - & - & - & - & - & - & - & - \\
\hline South Africa & & 2,547 & - & - & - & - & - & - & - & - \\
\hline Spain & & 1,832 & - & - & - & - & - & - & - & - \\
\hline \multirow[t]{2}{*}{ (Schaufeli et al., 2006) } & & $(14,521)$ & CFA 9 (one) & 0.80 & 22.76 & 0.89 & 0.89 & 0.91 & 0.04 & - \\
\hline & & & CFA 9 (three) & & 13.45 & 0.93 & 0.95 & 0.96 & 0.03 & - \\
\hline \multirow{2}{*}{$\begin{array}{l}\text { Sweden (Hallberg and Schaufeli, } \\
\text { 2006) }\end{array}$} & Information & 186 & CFA 9 (one) & 0.93 & 4.12 & 0.95 & - & 0.97 & 0.13 & 0.05 \\
\hline & Communication & & CFA 9 (three) & & 3.91 & 0.96 & - & 0.97 & 0.13 & 0.04 \\
\hline & & & & & & & & & & \\
\hline \multirow[t]{3}{*}{ China (Yi-wen and Yi-qun, 2005) } & Middle School Teachers & 277 & CFA 15 (one) & 0.90 & 2.74 & - & 0.89 & 0.89 & 0.081 & - \\
\hline & & & CFA 15 (three) & & 2.83 & - & 0.89 & 0.89 & 0.083 & - \\
\hline & & & CFA 15 (three - Mod.) & & 1.55 & - & 0.94 & 0.97 & 0.046 & - \\
\hline
\end{tabular}


TABLE 1 | Continued

\begin{tabular}{|c|c|c|c|c|c|c|c|c|c|c|}
\hline Country (Authors) & Occupational group & $N$ & Items version (factors) & Total $\alpha$ & $\chi^{2} / d f$ & TLI/NNFI & GFI & CFI & RMSEA & SRMR \\
\hline \multirow{4}{*}{$\begin{array}{l}\text { South Africa (Storm and } \\
\text { Rothmann, 2003) }\end{array}$} & Police Officers & 2,396 & CFA 17 (three) & - & 17.06 & 0.91 & 0.90 & 0.92 & 0.08 & - \\
\hline & & & CFA 17 (one) & & 18.91 & 0.90 & 0.87 & 0.91 & 0.09 & - \\
\hline & & & CFA 15 (three) & - & 13.30 & 0.93 & 0.94 & 0.95 & 0.07 & - \\
\hline & & & CFA 13 (one) & - & 12.34 & 0.95 & 0.95 & 0.96 & 0.06 & - \\
\hline Germany (Sonnentag, 2003) & Public Service & 147 & PCA 17 (one) & 0.91 & - & - & - & - & - & - \\
\hline
\end{tabular}

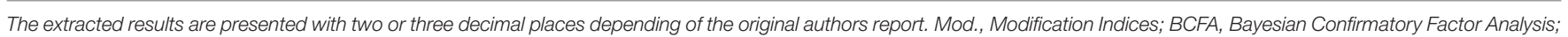

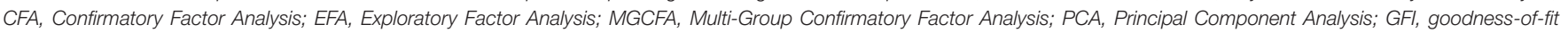

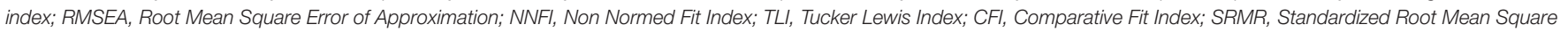
Residual.

Analysis. Thus, we included more studies, allowing a more global perspective on UWES versions. The UWES has also been used among different occupational groups (e.g., students, hospital staff, managers, police officers, teachers), and a study by Seppälä et al. (2009) showed that the UWES-9's structure, but not the UWES-17's structure, remained relatively unchanged among the different occupational groups. Extremera et al. (2012) found factorial invariance for the Spanish UWES-15 between genders in a multi-occupational sample, and between two different multi-occupational samples. More recently, RodríguezMontalbán et al. (2014) concluded that the UWES-9 has a better fit to a tri-factorial structure, while Hernandez-Vargas et al. (2016) confirmed the three-factorial structure in the UWES-9 and UWES-17 scales, concluding that the UWES-9 showed a better goodness-of-fit and measurement invariance among two Mexican samples.

While researchers have translated the UWES' student version into Portuguese (UWES-S, version of 14-item from UWES-17) and confirmed its good psychometric properties or invariance (Schaufeli et al., 2002a; Cadime et al., 2016), there is a lack of rigorous validation studies with either version of the UWES among Portuguese workers. Some studies used the 24-item original version (e.g., Picado et al., 2008), while others used only the vigor and dedication "core" work engagement scales (e.g. Chambel, 2012), thereby jeopardizing a better understanding of work engagement among Portuguese workers. Additionally, cross-cultural studies with the UWES among students were performed in several countries, including the Philippines and Argentina (Mesurado et al., 2016), Spain and the Netherlands (Schaufeli et al., 2002a), Turkey (Çapri et al., 2017), Ecuador (Portalanza Chavarría et al., 2017), South Africa (Mostert et al., 2017), South Korea (Römer, 2016), Puerto Rico (SánchezCardona et al., 2016), India (Rastogi et al., 2017), Japan (Tsubakita et al., 2017), Lithuania (Paradnike and Bandzevičiene, 2015), China (Meng and Jin, 2017), and the USA (Mills et al., 2012), looking for the cultural influences and impact of national values on participants and organizations (Hofstede et al., 2010).

To perform cross-cultural studies, including personality assessment (Dana, 2000), or to compare constructs within nations (Davidov et al., 2014), equivalent construct measurements are required, allowing meaningful comparisons of means or/and relations between constructs. The latent structure and its items should have stability across countries (measurement invariance according to van de Schoot et al., 2015). Although this seems to be a logical prerequisite, measurement invariance is rarely tested as it should be (Davidov et al., 2014), and sometimes when it is tested, it is done without adequate parametrization for ordinal items (Koh and Zumbo, 2008; Hirschfeld and von Brachel, 2014). If measurement invariance is not obtained, the constructs' meaning is different and means of each group cannot be compared (Putnick and Bornstein, 2016). Considering the existence of a Brazilian UWES version (Vazquez et al., 2015) but the absence of a Portuguese version for multi-occupational groups, and, especially, the absence of a UWES-9 version adapted simultaneously for both countries, it seems crucial to develop a unique version that will allow development of comparative studies of workers' work engagement in Portugal and Brazil. This version would be useful for future studies extended to other countries with Portuguese as the official language, such as the African Nations of Angola and Mozambique, Guinea-Bissau, Cape-Verde and São Tomé and Príncipe. Response bias is more likely to occur with long and time-consuming scales, while short versions tend to reduce this kind of bias. They are also easier to use, especially when they are used with other scales.

As far as we know, this is the first study using the same UWES version developed for both countries. We aim to assess the validity evidence related to the internal structure of the Portuguese version (PT-BR and PT-PT) of the original Utrecht Work Engagement Scale 9 items version (Schaufeli et al., 2006). More specifically, we evaluated: the UWES' Dimensionality, measurement invariance, and Reliability of the scores accordingly to the Standards for Educational and Psychological Testing framework (American Educational Research Association, 2014), and the existence of a work engagement second-order factor. We compared the fit of the original UWES-9 tri-factorial structure between Brazil and Portugal, considering cultural similarities between samples of Brazilian and Portuguese workers, and also the existence of numerous versions of UWES; we hypothesized: (H1) the original UWES-9 three-factor first-order structure will present evidence of construct validity; (H2) an invariant structure for both countries; (H3) and will show a secondorder latent factor, work engagement, with validity evidence that supports its usage among workers from Portugal and Brazil; (H4) the UWES-9 second-order latent factor model will show measurement invariance between countries; and, (H5) UWES-9's dimensions will present different mean scores for Brazilian and Portuguese workers due to socio-cultural differences between the two countries. 


\section{METHOD}

\section{Participants}

A sample of 524 Brazilian workers and a sample of 522 Portuguese workers completed the UWES-9. Participation was anonymous and voluntary. The average age was 35.57 years old $(S D=10.04)$, with $64 \%$ being female. Using the International Standard Classification of Occupations - ISCO-08 (International Labour Office, 2012) to allow for comparisons between countries, worker's occupations were mainly categorized as professional or administrative support (Table 2). Regarding educational level, $78 \%$ of the sample had, at the least, graduated from college. The high percentage of Masters in Portugal is due to recent changes in graduation, corresponding mostly to integrated masters, which are similar to college graduation in Brazil. We used nonprobabilistic convenience sampling, with the following inclusion criteria: all participants had, as workers, a contract or formal ties with their employers, were able to read, and had easy access to a PC, smartphone or tablet, to access the online platform where the instruments were deployed.

\section{Measures}

To assess work engagement, we used the Utrecht Work Engagement Scale short version UWES-9 (Schaufeli and Bakker, 2003), developing a new version for the Portuguese language transculturally adapted both for Brazil and Portugal (Table 3). The UWES-9 is a self-report scale scored on a 7-point rating scale ( $0=$ never; 6 = always) with three questions each about the three dimensions of vigor, dedication, and absorption. The UWES-9 was chosen because previous research with the UWES9 has shown validity evidence across different countries such as Japan, Spain, Norway and China (Shimazu et al., 2008; Nerstad et al., 2010; Fong and Ng, 2012).
Thus, to develop this Portuguese version, we used UWES' original manual (Schaufeli and Bakker, 2003) and we followed the International Test Commission guidelines for translating and adapting tests (International Test Commission, 2017) adapting the items to the Portuguese language per the Orthographic Agreement signed by both Portugal and Brazil in 2009. We discussed the items with Portuguese and Brazilian specialists on psychology and methodology, to create a version of the items that gathered the consensus of the specialists regarding the cultural, semantic and idiomatic equivalence in both countries. Finally, we did a small pilot test with 15 workers from each country, who didn't suggest any modifications and understood the adapted UWES-9 items. The final single version (for both countries) had no other changes besides the translation to adapt words according to each country's specificities.

\section{Procedures}

Data were gathered from 2014 to 2017, simultaneously in both countries, in an effort to respect each institution's authorization and to have a larger sample, since web surveys present low response rates (Massey and Tourangeau, 2013). The participants filled a self-report psychometric instrument (UWES-9) and a brief sociodemographic questionnaire, both of which were available online using LimeSurvey software (Limesurvey $\mathrm{GmbH}$, 2017) running on the website of each faculty in each country. Using several contact persons, researchers invited, in person or via e-mail, 260 Portuguese and 280 Brazilian companies to disseminate the study and ask for voluntary participation among nearby 1,500 workers of each country. Nearly $35 \%$ of the disseminated questionnaires were completed in both countries. Before they completed the survey, some information about the study was presented, explaining the aims and explaining that it was a research study where the company would not

TABLE 2 | Percentage of occupational groups for each country and total.

\begin{tabular}{|c|c|c|c|}
\hline & Brazil $(n=524)$ & Portugal $(n=522)$ & Total $(N=1,046)$ \\
\hline \multicolumn{4}{|l|}{ OCCUPATIONAL GROUPS } \\
\hline Armed Forces Occupations & 1.32 & 4.78 & 3.07 \\
\hline Managers & 16.56 & 9.35 & 12.92 \\
\hline Professionals & 33.77 & 51.74 & 42.83 \\
\hline Technicians and Associate Professionals & 9.27 & 13.48 & 11.39 \\
\hline Clerical Support Workers & 28.26 & 9.35 & 18.73 \\
\hline Services and Sales Workers & 6.18 & 6.30 & 6.24 \\
\hline Skilled Agricultural, Forestry and Fishery Workers & - & - & - \\
\hline Craft and Related Trades Workers & 1.99 & 2.39 & 2.19 \\
\hline Plant and Machine Operators and Assemblers & 0.88 & 0.65 & 0.77 \\
\hline Elementary Occupations & 1.77 & 1.96 & 1.86 \\
\hline \multicolumn{4}{|l|}{ ACADEMIC LEVEL } \\
\hline PhD & 5.18 & 5.26 & 5.22 \\
\hline Master & 9.07 & 38.11 & 23.77 \\
\hline Post-graduation (not master neither PhD) & 23.97 & 9.90 & 16.84 \\
\hline Graduation & 34.77 & 29.26 & 31.98 \\
\hline Unfinished graduation & 12.96 & 4.84 & 8.85 \\
\hline High school, vocational education or less & 14.05 & 12.63 & 13.34 \\
\hline
\end{tabular}




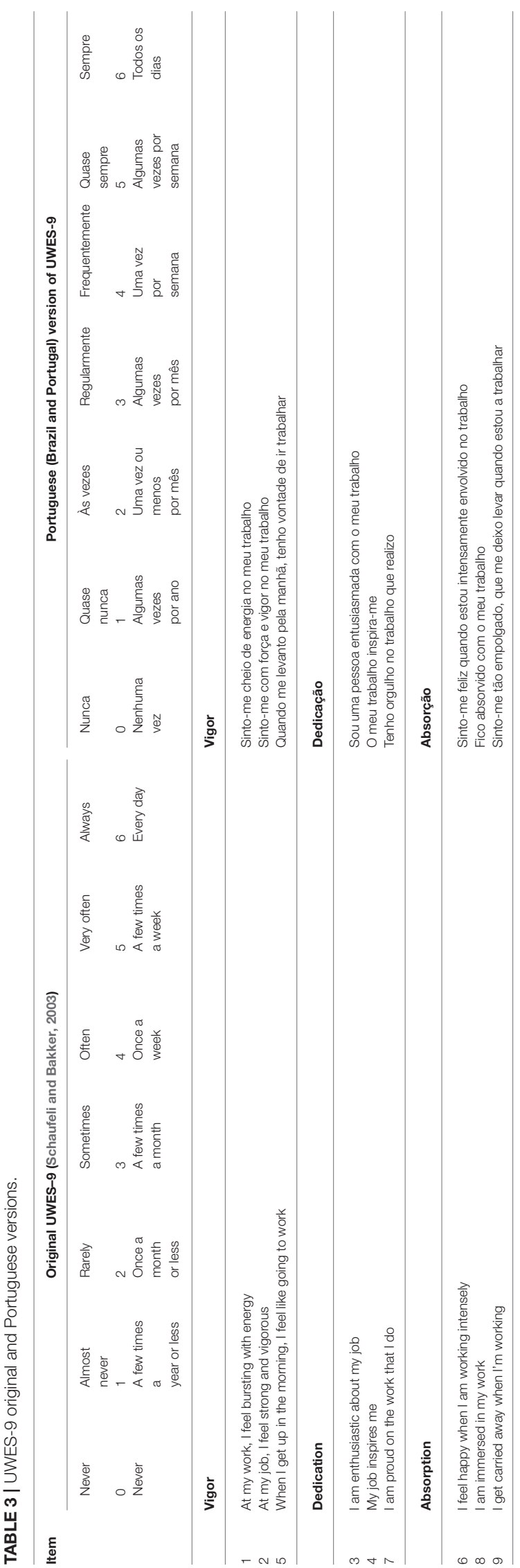

access individual data, and that companies simply helped the researchers disseminating the study. Informed consent was obtained online from all participants. The online survey presented, to begin with, information about the study's aims (and an institutional mail to answer doubts if the participant wanted), and also the Consent Form: "I agree to participate in this research study. I understand the purpose and nature of this study and I'm participating voluntarily. My answers in this study will remain confidential. I can withdraw my participation at any time." If the person agreed to participate, then he/she clicked "Yes" and was prompted to begin completing the survey. Upon completing the survey, participants were presented the sentence: "Thank you for your participation. It is not possible to identify your questions individually and the analysis will be performed as aggregated data by university researchers," aiming to reinforce the confidential nature of data.

To allow comparative studies, the same procedures were used in both countries. The study was approved by the Ethics Committee of the University of Porto, Portugal, and the University of São Paulo, Brazil, and followed the usual rules for online surveys, namely no access of participants' companies to individual results, and no direct contact between participants and researchers (a few used the email to clarify some details about the access to individual data, but it is not possible to identify if they participated in the study).

\section{Data Analysis}

Aiming to confirm the original structure of the instrument, a confirmatory factor analysis (CFA) was conducted to verify if the proposed 3-factor structure presented an adequate fit to the study sample. We used as the goodness-of-fit indices the TLI (Tucker Lewis Index), NFI (Normed Fit Index), $\chi^{2} / \mathrm{df}$ (ratio chi-square and degrees of freedom), CFI (comparative fit index) and the RMSEA (root mean square error of approximation). The fit of the model was considered good for $\chi^{2} / \mathrm{df}$ smaller than 5 , CFI, NFI and TLI values above 0.95 and RMSEA values below 0.08 (Hoyle, 1995; Boomsma, 2000; McDonald and Ho, 2002; Byrne, 2016). All statistical analyses were performed with R (R Core Team, 2017) and Rstudio (RStudio Team, 2017). The descriptive statistics were obtained with the skimr package (Arino de la Rubia et al., 2017). The CFA analysis was conducted with the lavaan package (Rosseel, 2012) using the Weighted Least Squares Means and Variances (WLSMV) estimation method.

To analyze the convergent validity evidence, the average variance extracted (AVE) was estimated as described in Fornell and Larcker (1981) and Marôco (2014). Values of AVE $\geq 0.5$ were considered indicative of the constructs' convergent validity evidence of the UWES' factors (Hair et al., 2009).

For discriminant validity evidence, to check if the items that represent a dimension were not strongly correlated with other dimensions (Marôco, 2014), discriminant validity evidence was checked (Fornell and Larcker, 1981; Marôco, 2014): for two factors $x$ and $y$, if $\operatorname{AVE} x$ and $\operatorname{AVE} y \geq \rho_{x y}^{2}$ (squared correlation between the factors $x$ and $y$ ) there is discriminant validity evidence.

The reliability of the scores was assessed with estimates of internal consistency, the Composite Reliability (CR), ordinal $\alpha$ 
(Oliden and Zumbo, 2008) and $\omega$ (Raykov, 2001); higher values were indicative of better internal consistency results.

The reliability estimates and measurement invariance for the first-order three-factor model taking in account the categorical items with theta-parameterization (Millsap and Yun-Tein, 2004) were calculated with the semTools package (SemTools Contributors, 2016). Measurement invariance for the secondorder model was assessed with the lavaan package (Rosseel, 2012), comparing a group of seven different models based on the recommendations of Millsap and Yun-Tein (2004) and on the second-order models' invariance specificities (Chen et al., 2005): (a) configural invariance, (b) first-order factor loadings, (c) second-order factor loadings, (d) thresholds of measured variables, (e) intercepts of first-order factors, (f) disturbances of first-order factors, and ( $\mathrm{g}$ ) residual variances of observed variables. The percentiles were calculated using the doBy package (Højsgaard and Halekoh, 2016). The comparisons of the raw levels of the UWES' factors between countries' groups were addressed using a $t$-student test for independent groups using the stats package (R Core Team, 2017). The effect sizes (Cohen's $d$ ) were calculated using the lsr package (Navarro, 2015).

\section{RESULTS}

\section{Validity Evidence Based on Internal Structure \\ Dimensionality \\ Items' distributional properties}

Summary measures, skewness $(s k)$, kurtosis $(k u)$ and a histogram for each of the nine items are presented (Table 4) and were used to judge distributional properties and psychometric sensitivity. Absolute values of $k u$ smaller than 7 and sk smaller than 3 were considered as indicative of no strong deviations from the normal distribution (Finney and DiStefano, 2013). The Mardia's Multivariate Kurtosis for the nine items of UWES was 90.36; $p<0.001$. All possible answer values for each item were also present, and no outliers were deleted. These items' distributional properties are indicative of appropriate psychometric sensitivity, as it would be expected that these items would follow an approximate normal distribution in the population under study. Despite these univariate and multivariate normality indicators, the WLSMV estimator was used, taking into consideration the ordinal level of measurement of the items.

\section{Factor related validity evidence}

The 3-factor model fit to the data was acceptable (Figure 1), since CFI, NFI, and TLI values were above 0.95 , but RMSEA values were above 0.10 , while the factor weight of all items was above 0.84 .

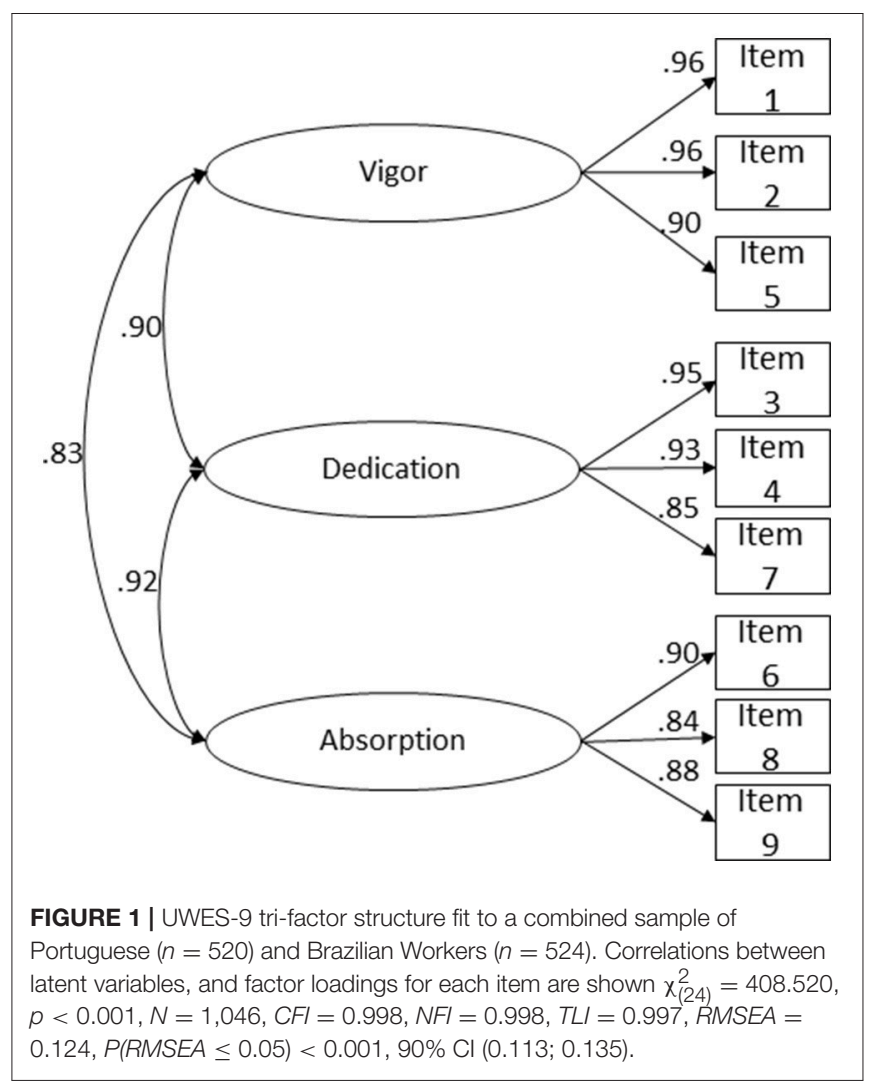

TABLE 4 | UWES' items descriptive statistics.

\begin{tabular}{|c|c|c|c|c|c|c|c|}
\hline UWES-9 items & Mean & $S D$ & Minimum & Maximum & Skewness & Kurtosis & Histogram \\
\hline UWES1V & 4.14 & 1.38 & 0 & 6 & -0.73 & -0.09 & \\
\hline UWES3 ${ }^{\mathrm{D}}$ & 4.31 & 1.54 & 0 & 6 & -0.84 & -0.15 & \\
\hline UWES4 ${ }^{\mathrm{D}}$ & 4.05 & 1.72 & 0 & 6 & -0.66 & -0.59 & \\
\hline UWES7 ${ }^{D}$ & 4.72 & 1.53 & 0 & 6 & -1.37 & 1.26 & \\
\hline UWES 8 A & 4.44 & 1.51 & 0 & 6 & -1.04 & 0.45 & \\
\hline UWES9A & 3.98 & 1.71 & 0 & 6 & -0.70 & -0.40 & \\
\hline
\end{tabular}

V, Vigor items; D, Dedication items; A, Absorption items. 


\section{Convergent validity evidence}

The AVE was good, for Vigor (0.89), for Dedication (0.83) and Absorption (0.76). These results suggest good convergent validity evidence for the UWES-9 and demonstrated that items contained within each factor are related to each other.

\section{Discriminant validity evidence}

Regarding the discriminant validity evidence, $A V E_{\text {vigor }}=0.89$ and $A V E_{\text {dedication }}=0.83$ were bigger than $r_{\mathrm{VD}}^{2}=0.81$, the $A V E_{\text {absorption }}=0.76$ and $A V E_{\text {dedication }}=0.83$ were both smaller than $r_{\mathrm{AD}}^{2}=0.85$, and the $A V E_{\mathrm{vigor}}=0.89$ and and the $A V E_{\text {absorption }}=0.76$ were both bigger than $r_{\mathrm{VA}}^{2}=0.69$. The discriminant validity evidence was good between Vigor and Absorption and between Vigor and Dedication, and bad between Dedication and Absorption. These findings showed that some factors are strongly related to each other.

\section{Second-order construct}

Second-order models are potentially applicable when the firstorder factors are highly correlated with each other, and when there is a higher order factor that possibly is responsible for the relations between the first-order factors (Chen et al., 2005; Marôco, 2014).

Considering the high correlations between Vigor, Dedication and Absorption and the lack of discriminant validity evidence between the Dedication and Absorption factors, we added a second-order factor that we named Work Engagement. The goodness-of-fit of the second-order model was considered acceptable (Figure 2), and the loadings of Work Engagement on its first-order factors were quite high and statistically significant $(p<0.001)$ : 0.88 for Vigor, 0.98 for Dedication and 0.94 for Absorption, suggesting that the second-order factor is equally defined by the first-order dimensions of the work engagement scale.

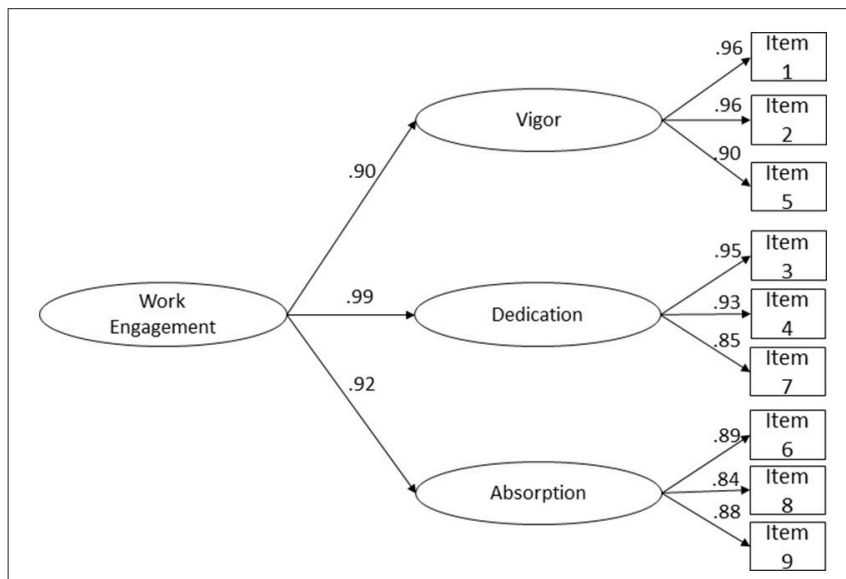

FIGURE 2 | UWES-9 second-order latent factor structure fit a combined sample of Portuguese $(n=522)$ and Brazilian Workers $(n=524)$.

Second-order latent loadings for each factor, and factor loadings for each item are shown $\chi_{(25)}^{2}=409.919, p<0.001, N=1,046, C F I=0.998, N F I=0.998$, $T L I=0.997, R M S E A=0.121, P(R M S E A \leq 0.05)<0.001,90 \% \mathrm{Cl}(0.111$; $0.132)$.
Considering previous analysis and high correlations between the factors, we propose that the UWES-9 can be used to define work engagement as a second-order factor (Chen et al., 2005). This model was supported by the data, showing better goodnessof-fit indices than the three-factor (one-order) solution. This indicates that in addition to the three UWES subdimensions, there is also a more general domain-specific work engagement. With this solution, we keep aligned with the theoretical threefactor division of UWES (Schaufeli and Bakker, 2003), but also show that work engagement can be a second-order dimension.

\section{Reliability of the Scores: Internal Consistency Evidence}

Regarding internal consistency (Table 5), ordinal Cronbach's $\alpha$ for the total sample was 0.95 , suggesting very good internal consistency evidence. Additionally, we presented other ordinal reliability estimates (CR and $\omega$ ) to allow future comparisons with other studies. Those other estimates also presented good internal consistency evidence.

The proportion of the second-order factor explaining the variance at first-order factors' level $\left(\omega_{\mathrm{L} 2}\right)$ was 0.96 , the proportion of the second-order factor explaining the total score $\left(\omega_{\mathrm{L} 1}\right)$ was 0.93 , and the proportion of observed variance explained by the second-order factor after controlling for the uniqueness from the first-order factor $\left(\omega_{\text {partialL1 } 1}\right)$ was 0.97 . Thus, the internal consistency of the higher-order construct was very good.

\section{Measurement Invariance}

To detect whether the same original three-factor model holds in each country (Table 6), a group of nested models with indications of equivalence is needed (Marôco, 2014). This should be done considering the ordinal nature of the scale. Thus, we tested measurement invariance for categorical items with thetaparameterization. Full uniqueness measurement invariance was supported by the Cheung and Rensvold (2002) criterion ( $\Delta$ CFI $<$ 0.01 ), and also partial scalar invariance by the (more) restrictive $\Delta \chi^{2}$ criterion (Satorra and Bentler, 2001); the test comparing the fit of the constrained vs. free models is not statistically significant. Results supported the structural invariance between Portugal and Brazil.

Regarding the UWES-9 second-order three-factor structure, full uniqueness measurement invariance was supported by the Cheung and Rensvold (2002) criterion $(\Delta \mathrm{CFI}<0.01)$, and the $\Delta \chi^{2}$ (Satorra and Bentler, 2001) supported (partial) scalar invariance for the models comparison between countries (Table 7).

TABLE 5 | Internal consistency of UWES dimensions.

\begin{tabular}{lccc}
\hline $\begin{array}{l}\text { UWES-9 } \\
\text { dimension }\end{array}$ & Ordinal $\boldsymbol{\alpha}_{\text {Total sample }}$ & Ordinal $\boldsymbol{\omega}_{\text {Total sample }}$ & CR Total sample \\
\hline Vigor & 0.93 & 0.94 & 0.96 \\
Dedication & 0.93 & 0.92 & 0.94 \\
Absorption & 0.90 & 0.88 & 0.91 \\
Total & 0.96 & 0.97 & -
\end{tabular}


TABLE 7 | UWES-9 second-order three-factor latent model comparison between countries.

\begin{tabular}{|c|c|c|c|c|c|c|}
\hline Model & $x^{2}$ & $d f$ & $\chi^{2} / d f$ & CFI scaled & $\Delta \chi^{2}$ & $\Delta C F I$ scaled \\
\hline Configural (factor structure) & 455.06 & 48 & 9.48 & 0.985 & - & - \\
\hline First-order loadings invariance & 457.74 & 54 & 8.48 & 0.985 & $3.58^{n s}$ & 0.000 \\
\hline $\begin{array}{l}\text { Second-order loadings } \\
\text { invariance }\end{array}$ & 458.71 & 56 & 8.19 & 0.986 & $1.53^{\text {ns }}$ & 0.001 \\
\hline $\begin{array}{l}\text { Thresholds of measured } \\
\text { variables }\end{array}$ & 501.94 & 98 & 5.12 & 0.988 & $33.33^{\star}$ & 0.002 \\
\hline $\begin{array}{l}\text { Intercepts of first-order factors } \\
\text { invariance }\end{array}$ & 533.43 & 101 & 5.28 & 0.994 & $2.50^{n s}$ & 0.006 \\
\hline $\begin{array}{l}\text { Disturbances of first-order } \\
\text { factors invariance }\end{array}$ & 588.54 & 107 & 5.50 & 0.994 & $43.57^{\star \star \star}$ & 0.000 \\
\hline $\begin{array}{l}\text { Residual variances of observed } \\
\text { variables invariance }\end{array}$ & 733.89 & 116 & 6.33 & 0.993 & $73.06^{\star \star \star}$ & 0.001 \\
\hline
\end{tabular}

${ }^{n s} p>0.05 ;{ }^{*} p<0.05 ;{ }^{* \star *} p<0.001$.

TABLE 6 | Model comparison between Portugal and Brazil.

\begin{tabular}{|c|c|c|c|c|c|c|}
\hline $\begin{array}{l}\text { Model } \\
\text { invariance }\end{array}$ & $\chi^{2}$ & $d f$ & $\chi^{2} / d f$ & CFI scaled & $\Delta \chi^{2}$ & $\Delta C F I$ scaled \\
\hline $\begin{array}{l}\text { Configural } \\
\text { (factor } \\
\text { structure) }\end{array}$ & 455.06 & 48 & 9.48 & 0.985 & - & - \\
\hline $\begin{array}{l}\text { Metric } \\
\text { (loadings) }\end{array}$ & 457.74 & 54 & 8.48 & 0.985 & $4.88^{n s}$ & 0.000 \\
\hline $\begin{array}{l}\text { Scalar } \\
\text { (thresholds) }\end{array}$ & 500.83 & 96 & 5.22 & 0.987 & $66.62^{\star \star}$ & 0.002 \\
\hline $\begin{array}{l}\text { Full } \\
\text { uniqueness } \\
\text { (residuals) }\end{array}$ & 609.22 & 105 & 5.80 & 0.986 & $100.97^{\star \star * \star}$ & 0.002 \\
\hline $\begin{array}{l}\text { Latent } \\
\text { means }\end{array}$ & 619.79 & 108 & 5.74 & 0.993 & $0.439^{n s}$ & 0.008 \\
\hline
\end{tabular}

${ }^{n s} p>0.05 ;{ }^{* *} p<0.01 ;{ }^{* * *} p<0.001$

\section{Dimensions' Comparisons}

Finally, since we had measurement invariance between samples, we performed a comparative analysis of the UWES dimensions between the two countries (Table 8). There were no statistically significant differences on the UWES dimensions between Portuguese and Brazilian workers.

\section{DISCUSSION}

Our results confirmed four of the five hypotheses. The UWES9 tri-factorial first-order model showed validity evidence that allows its use among workers from Brazil and Portugal (H1). This result is in line with several studies showing that the UWES-9 three-factor first-order model has acceptable (at least) psychometric properties (Villotti et al., 2014; Flores Jiménez et al., 2015; Vazquez et al., 2015; Sinval et al., 2018), although other studies presented better fit with other alternative model structures (de Bruin and Henn, 2013; Ho Kim et al., 2017).

Our results also revealed that this version of the UWES9 presented measurement invariance for Portugal and Brazil, which allows its use in comparative studies between these countries and confirms the second hypothesis (H2). In fact, measurement invariance has also been found between other countries: samples of white-collar workers from the Netherlands and Italy presented metric invariance (Balducci et al., 2010); UWES-15 version between Greek and Dutch workers (Xanthopoulou et al., 2012); the student version (UWESS) presented invariance only for the absorption dimension among samples of students from Portugal, Spain, and the Netherlands (Schaufeli et al., 2002a). Our findings support the need for more studies to test measurement invariance across countries (Schaufeli et al., 2006). Other studies demonstrated factorial invariance for members of the same occupational group between different countries or ethnic groups (Storm and Rothmann, 2003), which, in turn, makes UWES' measurement invariance more likely. Additionally, no factorial invariance across samples from various countries of different continents was found in the study of Schaufeli et al. (2006).

Regarding the third hypothesis, the second-order latent factor work engagement was proposed following concerns with the high correlations between the three latent factors of the UWES-9 found in various studies (Schaufeli et al., 2002b; Schaufeli and Bakker, 2003). Our results confirmed H3, and this kind of approach isn't a novelty in the sense that others tried this with two first-order latent factors, vigor and dedication (Alok, 2013) and with three first-order latent factors (Sinval et al., 2018). However, in the first study a one-factor model presented better fit, and in the second study the second-order model had a better fit than the first-order one in a Portuguese sample of rescue workers. Moreover, no studies with second-order UWES' models were found for samples of workers from Brazil.

Concerning the measurement invariance of this second-order model (H4), our study obtained a novel finding, since we found measurement invariance for the level of residual variances of observed variables across samples of workers from various occupational groups of both countries. Partial metric invariance was found before (Sinval et al., 2018) for a second-order model across different occupations (firefighters, nurses, and police officers), although this is the first study that presents full 
TABLE 8 | Comparative analysis between countries (means, SD and percentiles).

\begin{tabular}{|c|c|c|c|c|c|c|c|c|c|c|c|c|c|c|}
\hline \multirow[t]{2}{*}{ UWES-9 dimension } & \multicolumn{2}{|c|}{ Brazil $(n=524)$} & \multicolumn{2}{|c|}{ Portugal $(n=520)$} & \multirow[t]{2}{*}{$t$-student } & \multirow[t]{2}{*}{$d f$} & \multirow[t]{2}{*}{$p$} & \multirow[t]{2}{*}{ Cohen's d } & \multicolumn{3}{|c|}{ Brazil } & \multicolumn{3}{|c|}{ Portugal } \\
\hline & $M$ & $S D$ & $M$ & $S D$ & & & & & 25 & 50 & 75 & 25 & 50 & 75 \\
\hline Vigor & 4.02 & 1.46 & 4.00 & 1.35 & 0.21 & 1,044 & 0.83 & 0.01 & 3.00 & 4.00 & 5.00 & 3.00 & 4.33 & 5.00 \\
\hline Dedication & 4.39 & 1.52 & 4.34 & 1.41 & 0.56 & 1,044 & 0.57 & 0.03 & 3.33 & 5.00 & 5.67 & 3.33 & 4.67 & 5.33 \\
\hline Absorption & 4.33 & 1.46 & 4.31 & 1.4 & 0.33 & 1,044 & 0.74 & 0.02 & 3.33 & 4.67 & 5.67 & 3.67 & 4.67 & 5.33 \\
\hline
\end{tabular}

measurement invariance across different countries for a secondorder model of the UWES-9, which is particularly interesting given the fact that these two countries are from different continents. The vast majority of the studies on work engagement were conducted in countries from North America and Western Europe (Hu et al., 2014), but our study included a South America country that can be compared with a European country regarding work engagement.

The dimensions of UWES-9 didn't present statistically significant different levels between Brazil and Portugal, rejecting $\mathrm{H} 5$, formulated based on socio-cultural differences between these countries. However, no other studies comparing Portugal and Brazil in terms of work engagement with this instrument were found, since other studies measured the three UWES dimensions in Portugal and Brazil individually in various occupations (Marques-Pinto and Picado, 2011; Vazquez et al., 2015), using different versions of the instrument; thus, their findings could not be directly compared with ours. This enforces the utility of using our version of the UWES-9 to establish larger comparisons with rigor between two brother countries. Maybe socio-cultural differences are not so strong between Portugal and Brazil, or since data were collected during the world economic crisis, the workers are thankful to have a job (work engagement levels are moderate to high) and work engagement levels are not affected by the country. Having now a unique instrument in the Portuguese language, further studies can be developed, since cross-cultural studies between Portugal-Brazil are not that frequent.

After presenting a revision of the international versions of Utrecht Work Engagement Scale, this paper aimed to investigate the validity evidence related to the scale dimensionality of the Portuguese version of the UWES-9 developed simultaneously for Brazil and Portugal, namely, dimensionality, measurement invariance between Brazil and Portugal, and reliability of the scores. Our version showed good convergent validity evidence and acceptable discriminant validity evidence, and measurement invariance evidence for both the first- and second-order models for use in the Portuguese vs. Brazilian cultural context. The goodness-of-fit indices were good/acceptable for the UWES nine item version. This solution is corroborated by some international studies and may have been found because work engagement, as measured by the UWES, is a construct with high correlations between factors (Mauno et al., 2007; Hakanen et al., 2008; Weigl et al., 2010; Federici and Skaalvik, 2011; Chughtai and Buckley, 2013; Agarwal, 2014). In fact, a meta-analytic study found very high correlations between UWES factors: 0.95 between vigor and absorption, 0.90 between dedication and absorption and 0.88 between vigor and dedication (Christian and Slaughter, 2007).
We suggested that a second-order latent factor might account for such intercorrelations, and in our study it presented an acceptable fit. It is very common that when conducting confirmatory factor analysis, a three-factor solution may not be clear, but still fits as a possible model to interpret the work engagement results (Schaufeli and Bakker, 2010).

Previous research showed (see Table 1) that the UWES-9 three-factor solution was invariant between Italy and Dutch white-collar workers samples (Balducci et al., 2010), but with two versions of the instrument, one in each language. Although measurement invariance wasn't obtained in a study between 10 countries with the UWES-9 (Schaufeli et al., 2006), the UWES showed invariance in South African police officers of different racial groups (Storm and Rothmann, 2003). Also, for different Japanese occupations, the UWES-9 (one factor) showed measurement invariance (Shimazu et al., 2008). For a Dutch, Spanish and Portuguese student sample, the UWES$S$ (student survey) showed invariance only for the Absorption factor across the three countries; three-factor structure invariance wasn't obtained (Schaufeli et al., 2002a). However, in this study, with a sample of Portuguese and Brazilian workers, the results revealed measurement invariance, allowing comparisons of means between these two countries using the same UWES-9 version. Our results are in line with those obtained by Seppälä et al. (2009), who analyzed five different studies $(N=9,404)$, including a three-year longitudinal study $(n=2,555)$ among different occupational samples, concluding that vigor, dedication, and absorption presented a correlated three-factor structure, and although the structure of the UWES-17 did not remain the same across the samples and time, the structure of the UWES-9 remained relatively unchanged. Although Schaufeli et al. (2006) argued that measurement invariance is less likely to be obtained between different occupational groups, Hernandez-Vargas et al. (2016) found invariance across two Mexican samples, and our results showed measurement invariance across countries with samples containing different occupational groups. Moreover, the UWES-9 showed different means and percentiles for each country, with Portugal presenting higher values for vigor and absorption, which could be explained by different cultural values (Hofstede et al., 2010) or occupational activities (see Table 2) related primarily to mental demands instead of physical demands, and thus increasing absorption levels. Cross-cultural analysis from $\mathrm{Hu}$ et al. (2014) compared work engagement across East Asia (China and Japan) and Western Europe (Finland, Netherlands, and Spain), concluding that European employees were more engaged than Asian employees. Recently, Schaufeli (2017) argued that work engagement seems to be 
positively related to nations' economic activity, and also with lower work centrality (thus valorizing leisure over work), strong democracy, high integrity, low corruption, gender inequality, and individualistic culture.

\section{CONCLUSION}

This Portuguese transcultural UWES-9 version has good construct validity evidence, and its use can be recommended in future research, namely to perform comparative studies between Portuguese-speaking countries or groups, to analyze work engagement's association with other recent constructs, such as job crafting as a protector from job boredom (Harju et al., 2016), the relationship of work engagement with productivity or person-job fit (De Beer et al., 2016; Fuller and Shikaloff, 2017), or occupational differences in work engagement (Innstrand, 2016) or to perform longitudinal studies (Seppälä et al., 2009). Additionally, we will be able to understand if these different groups/countries can differently perceive work engagement between them according to cultural and organizational values (Hofstede et al., 2010). Also, multi-cultural workforces that are increasing in each country (OECD, 2016) challenge researchers to pursue new research topics such as psychological assessment and interventions with multicultural populations (Dana, 2000; López, 2000). A transculturally valid UWES scale can aid research efforts to study migrant flows and employees' well-being and productivity between Portugal and Brazil.

The study has some limitations, namely the convenience sample and the fact that only those with a professional occupation participated. Additionally, the samples were dependent on voluntary participation, which can elicit some bias or reflect the healthy worker myth, which means that those who are satisfied participate more in research studies, while the most disengaged are too stressed to collaborate, according to Shah (2009). In the future, it will be important to also evaluate workers' situations as migrant or native, since it can affect their relationship with institutions and colleagues, thus influencing their work engagement. Moreover, other structures can be tested in the future, such as two latent factors (Gilchrist et al., 2013; Sulaiman and Zahoni, 2016).

Regarding theoretical implications, considering previous analysis and high correlations between the factors, we propose that the UWES-9 can be used to define work engagement as a second-order factor. This model was supported by the data, showing better goodness-of-fit indices than the three-factor (oneorder) solution. This indicates that in addition to the three UWES sub-dimensions, there is also a more general domain-specific work engagement. With this solution, we keep aligned with the theoretical three-factor division of the UWES, but also show that work engagement can be a second-order construct. This is one of the main novelties of our study.

\section{REFERENCES}

Agarwal, U. A. (2014). Linking justice, trust and innovative work behaviour to work engagement. Pers. Rev. 43, 41-73. doi: 10.1108/PR-02-2012-0019
As practical implications, the UWES-9 transcultural version presented acceptable psychometric properties and invariance between Portugal and Brazil, allowing cross-cultural studies between these countries. Recent international workforce flows present a challenge for human resource management, since migrants are used to increase productivity, but they can have different perceptions about the organization where they are employees (Pocnet et al., 2015; Wojczewski et al., 2015; Le et al., 2016). Migrant workers' work engagement with labor market has already attracted researchers' interest (Samaluk, 2016) and UWES seems to be an important measure to understand employees' work engagement in the organizations, allowing human resources departments to better adapt their practices to workforces, especially when the workers are migrants. Moreover, as Schaufeli (2017) recently argued, work engagement may not only be studied at the individual, psychological level, but also at the collective and national level as it relates in meaningful ways with various economic and sociocultural indicators, helping organizations to increase their productivity due to engaged workers who present high performance and job satisfaction (Christian et al., 2011).

\section{ETHICS STATEMENT}

This study was carried out in accordance with the recommendations of the Ethics guidelines, of the FPCEUP and FFCLRP-USP Ethics Committees with written informed consent from all subjects. All subjects gave written informed consent in accordance with the Declaration of Helsinki. The protocol was approved by the FPCEUP and FFCLRP-USP Ethics Committees.

\section{AUTHOR CONTRIBUTIONS}

All authors of this research paper have directly participated in the planning, execution, or analysis of this study. More specifically, JS wrote the paper, and with JM performed all statistical analysis and its discussion. JS and SP discussed cross-cultural topics, and JS and CQ discussed theoretical framework.

\section{FUNDING}

The authors would like to thank the Portuguese National Occupational Health Program of the Directorate-General of Health (DGS) for the sponsorship. And to the University of São Paulo (USP) International grant conceded to JS (Grant agreement number: 2014.1.3766.1.8). This work was funded by the Center for Psychology at the University of Porto, Portuguese Science Foundation (FCT UID/PSI/00050/2013) and EU FEDER through COMPETE 2020 program (POCI-01-0145-FEDER007294).

Alfes, K., Truss, C., Soane, E. C., Rees, C., and Gatenby, M. (2013). The relationship between line manager behavior, perceived HRM practices, and individual performance: examining the mediating role of engagement. Hum. Resour. Manage. 52, 839-859. doi: 10.1002/hrm.21512 
Alok, K. (2013). Work engagement in India: a factorial validation study of UWES-9 scale. Manag. Labour Stud. 38, 53-62. doi: 10.1177/0258042X134 91478

American Educational Research Association, American Psychological Association, and National Council on Measurement in Education (2014). Standards for Educational and Psychological Testing. Washington, DC: United States of America; American Psychological Association.

Arino de la Rubia, E., Zhu, H., Ellis, S., Waring, E., and Quinn, M. (2017). skimr: skimr (R Package Version 0.9100) [Computer software]. Available online at: https://github.com/ropenscilabs/skimr

Bakker, A. B., Rodríguez-Muñoz, A., and Derks, D. (2012). La emergencia de la psicología de la salud ocupacional positiva. Psicothema 24, 66-72.

Bakker, A. B., Schaufeli, W. B., Leiter, M. P., and Taris, T. W. (2008). Work engagement: an emerging concept in occupational health psychology. Work Stress 22, 187-200. doi: 10.1080/02678370802393649

Bal, P. M., and De Lange, A. H. (2015). From flexibility human resource management to employee engagement and perceived job performance across the lifespan: a multisample study. J. Occup. Organ. Psychol. 88, 126-154. doi: $10.1111 /$ joop. 12082

Balducci, C., Fraccaroli, F., and Schaufeli, W. B. (2010). Psychometric properties of the Italian version of the Utrecht Work Engagement Scale (UWES-9): a cross-cultural analysis. Eur. J. Psychol. Assess. 26, 143-149. doi: 10.1027/1015-5759/a000020

Boomsma, A. (2000). Reporting analyses of covariance structures. Struct. Equ. Model. A Multidiscip. J. 7, 461-483. doi: 10.1207/S15328007SEM0703_6

Breevaart, K., Bakker, A. B., Demerouti, E., and Hetland, J. (2012). The measurement of state work engagement: a multilevel factor analytic study. Eur. J. Psychol. Assess. 28, 305-312. doi: 10.1027/1015-5759/a000111

Byrne, B. M. (2016). Structural Equation Modeling with AMOS: Basic Concepts, Applications, and Programming, 3rd Edn. New York, NY Routledge.

Byrne, Z. S. (2014). Understanding Employee Engagement: Theory, Research, and Practice. New York, NY Routledge.

Cadime, I., Lima, S., Marques-Pinto, A., and Ribeiro, I. (2016). Measurement invariance of the utrecht work engagement scale for students: a study across secondary school pupils and university students. Eur. J. Dev. Psychol. 13, 254-263. doi: 10.1080/17405629.2016.1148595

Çapri, B., Gündüz, B., and Akbay, S. E. (2017). Utrecht Work Engagement ScaleStudent Forms' (UWES-SF): adaptation to Turkish, validity and reliability studies, and the mediator role of work engagement between academic procrastination and academic responsibility. Educ. Sci. Theory Pract. 17, 411-435. doi: 10.12738/estp.2017.2.0518

Chambel, M. J. (2012). Explaining nurses' engagement and performance with social exchange with hospital. Cienc. Trab. 14, 81-88.

Chambel, M. J. (ed.). (2016). Psicologia da Saúde Ocupacional. Lisboa: Pactor.

Chaudhary, R., Rangnekar, S., and Barua, M. K. (2012). Psychometric evaluation of utrecht work engagement scale in an Indian sample. Asia Pacific J. Manag. Res. Innov. 8, 343-350. doi: 10.1177/2319510X1200800314

Chaudhary, R., Rangnekar, S., Tanlamai, U., Rajkulchai, S., and Asawasakulsor, A. (2018). Work Engagement in India and Thailand: a comparative analysis. Glob. Bus. Rev. 19, 162-174. doi: 10.1177/0972150917713286

Chen, F. F., Sousa, K. H., and West, S. G. (2005). Teacher's corner: testing measurement invariance of second-order factor models. Struct. Equ. Model. A Multidiscip. J. 12, 471-492. doi: 10.1207/s15328007sem1203_7

Cheung, G. W., and Rensvold, R. B. (2002). Evaluating goodness-of-fit indexes for testing measurement invariance. Struct. Equ. Model. A Multidiscip. J. 9, 233-255. doi: 10.1207/S15328007SEM0902_5

Christian, M. S., Garza, A. S., and Slaughter, J. E. (2011). Work engagement: a quantitative review and test of its relations with task and contextual performance. Pers. Psychol. 64, 89-136. doi: 10.1111/j.1744-6570.2010. 01203.x

Christian, M. S., and Slaughter, J. E. (2007). Work engagement: a meta-analytic review and directions for research in an emerging area. Acad. Manag. Proc. 2007, 1-6. doi: 10.5465/AMBPP.2007.26536346

Chughtai, A. A., and Buckley, F. (2013). Exploring the impact of trust on research scientists' work engagement. Pers. Rev. 42, 396-421. doi: 10.1108/PR-06-2011-0097

Dana, R. H. (2000). "An assessment-intervention for research and practice with multicultural populations," in Handbook of Cross-Cultural and Multicultural
Personality Assessment, ed R. H. Dana (Mahwah, NJ: Lawrence Erlbaum Associates), 5-16.

Davidov, E., Meuleman, B., Cieciuch, J., Schmidt, P., and Billiet, J. (2014). Measurement equivalence in cross-national research. Annu. Rev. Sociol. 40, 55-75. doi: 10.1146/annurev-soc-071913-043137

De Beer, L. T., Rothmann, S., and Mostert, K. (2016). The bidirectional relationship between person-job fit and work engagement: a three-wave study. J. Pers. Psychol. 15, 4-14. doi: 10.1027/1866-5888/a000143

de Bruin, G. P., and Henn, C. M. (2013). Dimensionality of the 9-item Utrecht Work Engagement Scale (UWES-9). Psychol. Rep. 112, 788-799. doi: 10.2466/01.03.PR0.112.3.788-799

de Camargo, J. A., Liboni, L. B., and de Oliveira, J. H. C. (2015). Gestão ambiental de recursos humanos e nível de envolvimento de colaboradores nas organizações. Rev. Adm. Mackenzie 16, 72-91. doi: 10.1590/1678-69712015/administracao.v16n2p72-91

Direção-Geral da saúde, I. (2013). Programa Nacional de Saúde Ocupacional: $2^{\circ}$ ciclo - 2013/2017. Lisboa. Available online at: https://www.dgs.pt/saudeocupacional/programa-nacional4.aspx

Dollard, M. F., Shimazu, A., Bin Nordin, R., Brough, P., and Tuckey, M. R. (eds.). (2014). Psychosocial Factors at Work in the Asia Pacific. Dordrecht: Springer.

Dunkerley, D. (2013). Occupations and Society. Abingdon, OX: Routledge.

Eman-Nafa, A. (2016). Psychometrics of Arabic version of the UWES-9. Int. J. Appl. Innov. Eng. Manag. 5, 191-196.

European Agency for Safety and Health at Work (2016). Safer and Healthier Work at Any Age: Review of Resources for Workplaces. Bilbao: European Agency for Safety and Health at Work.

Extremera, N., Sánchez-García, M., Durán, M. A., and Rey, L. (2012). Examining the psychometric properties of the utrecht work engagement scale in two Spanish multi-occupational samples. Int. J. Sel. Assess. 20, 105-110. doi: $10.1111 / j .1468-2389.2012 .00583 . x$

Federici, R. A., and Skaalvik, E. M. (2011). Principal self-efficacy and work engagement: assessing a Norwegian principal self-efficacy scale. Soc. Psychol. Educ. 14, 575-600. doi: 10.1007/s11218-011-9160-4

Finney, S. J., and DiStefano, C. (2013). "Non-normal and categorical data in structural equation modeling," in Structural Equation Modeling: A Second Course, eds G. R. Hancock and R. O. Mueller (Charlotte, NC: Information Age Publishing), 439-492.

Flores Jiménez, C., Fernández Arata, M., Juárez García, A., Merino Soto, C., and Guimet Castro, M. (2015). Work engagement: a validity study in teaching professionals from Lima, Peru. Lib. Rev. Psicol. 21, 195-206.

Fong, T. C., and Ho, R. T. (2015). Dimensionality of the 9-item utrecht work engagement scale revisited: a Bayesian structural equation modeling approach. J. Occup. Health 57, 353-358. doi: 10.1539/joh.15-0057-OA

Fong, T. C., and Ng, S. (2012). Measuring engagement at work: validation of the Chinese version of the Utrecht Work Engagement Scale. Int. J. Behav. Med. 19, 391-397. doi: 10.1007/s12529-011-9173-6

Fornell, C., and Larcker, D. F. (1981). Evaluating structural equation models with unobservable variables and measurement error. J. Mark. Res. 18, 39-50. doi: $10.2307 / 3151312$

Fuller, R., and Shikaloff, N. (2017). Being Engaged at Work is Not the Same as Being Productive. Harvard Business Review, 2-5. Available online at: https://hbr.org/ 2017/02/being-engaged-at-work-is-not-the-same-as-being-productive

Gilchrist, R. M., Villalobos, C. E. P., and Fernández, L. R. (2013). Factorial structure and internal consistency of the Utrecht Work Engagement Scale (Uwes) 17 among health workers of Chile. Liberabit 19, 163-171.

Graffigna, G. (2017). Is a transdisciplinary theory of engagement in organized settings possible? A concept analysis of the literature on employee engagement, consumer engagement and patient engagement. Front. Psychol. 8:872. doi: 10.3389/FPSYG.2017.00872

Hair, J. F., Black, W. C., Babin, B. J., and Anderson, R. E. (2009). Multivariate Data Analysis. 7th Edn. Upper Saddle River, NJ: Prentice Hall.

Hakanen, J. J., Schaufeli, W. B., and Ahola, K. (2008). The job demandsresources model: a three-year cross-lagged study of burnout, depression, commitment, and work engagement. Work Stress 22, 224-241. doi: $10.1080 / 02678370802379432$

Hallberg, U. E., and Schaufeli, W. B. (2006). "Same same" but different? Eur. Psychol. 11, 119-127. doi: 10.1027/1016-9040.11.2.119 
Harju, L. K., Hakanen, J. J., and Schaufeli, W. B. (2016). Can job crafting reduce job boredom and increase work engagement? A three-year cross-lagged panel study. J. Vocat. Behav. 95-96, 11-20. doi: 10.1016/j.jvb.2016.07.001

Hernandez-Vargas, C. I., Llorens-Gumbau, S., Rodriguez-Sanchez, A. M., and Dickinson-Bannack, M. E. (2016). Validación de la escala UWES9 en profesionales de la salud en México. Pensam. Psicol. 14, 89-100. doi: 10.11144/Javerianacali.PPSI14-2.veup

Hirschfeld, G., and von Brachel, R. (2014). Multiple-group confirmatory factor analysis in R: a tutorial in measurement invariance with continuous and ordinal indicators. Pract. Assess. Res. Eval. 19, 1-12.

Hofstede, G., Hofstede, G. J., and Minkov, M. (2010). Cultures and Organizations: Software of the Mind, 3rd Edn. New York, NY: McGraw-Hill.

Højsgaard, S., and Halekoh, U. (2016). doBy: Groupwise Statistics, LSmeans, Linear Contrasts, Utilities (R package version 4.5-15) [Computer software]. Available online at: https://cran.r-project.org/package $=$ doBy

Ho Kim, W., Park, J. G., and Kwon, B. (2017). Work engagement in South Korea: validation of the Korean version 9-item Utrecht Work Engagement Scale. Psychol. Rep. 120, 561-578. doi: 10.1177/0033294117697085

Hoyle, R. H. (ed.). (1995). Structural Equation Modeling: Concepts, Issues and Applications. Thousand Oaks, CA: SAGE Publications.

Hu, Q., Schaufeli, W. B., Taris, T. W., Hessen, D. J., Hakanen, J. J., Salanova, M., et al. (2014). "East is east and west is west and never the twain shall meet:" Work engagement and workaholism across eastern and western cultures. J. Behav. Soc. Sci. 1, 6-24.

INE (2014). Revista de Estudos Demográficos. Lisboa: INE.

Innstrand, S. T. (2016). Occupational differences in work engagement: a longitudinal study among eight occupational groups in Norway. Scand. J. Psychol. 57, 338-349. doi: 10.1111/sjop. 12298

International Labour Office (2012). International Standard Classification of Occupations - ISCO-08: Structure, Group Definitions and Correspondence Tables. Geneva: International Labour Organization.

International Test Commission (2017). International Test Commission Guidelines for Translating and Adapting Tests, 2nd Edn. Available online at: www. InTestCom.org

Klassen, R. M., Aldhafri, S., Mansfield, C. F., Purwanto, E., Siu, A. F. Y., Wong, M. W., et al. (2012). Teacher' engagement at work: an international validation study. J. Exp. Educ. 80, 317-337. doi: 10.1080/00220973.2012.678409

Knight, C., Patterson, M., and Dawson, J. (2017). Building work engagement: a systematic review and meta-analysis investigating the effectiveness of work engagement interventions. J. Organ. Behav. 38, 792-812. doi: 10.1002/ job. 2167

Koh, K. H., and Zumbo, B. D. (2008). Multi-group confirmatory factor analysis for testing Measurement invariance in mixed item format data. J. Mod. Appl. Stat. Methods 7, 471-477. doi: 10.22237/jmasm/1225512660

Kruyen, P. M., Emons, W. H. M., and Sijtsma, K. (2013). On the shortcomings of shortened tests: a literature review. Int. J. Test. 13, 223-248. doi: 10.1080/15305058.2012.703734

Kulikowski, K. (2017a). Do we all agree on how to measure work engagement? Factorial validity of Utrecht Work Engagement Scale as a standard measurement tool - A literature review. Int. J. Occup. Med. Environ. Health 30, 161-175. doi: 10.13075/ijomeh.1896.00947

Kulikowski, K. (2017b). One, two or three dimensions of work engagement? Testing the factorial validity of the Utrecht Work Engagement Scale on a sample of Polish employees. Int. J. Occup. Saf. Ergon. 1-9. doi: 10.1080/10803548.2017.1371958

Lathabhavan, R., Balasubramanian, S. A., and Natarajan, T. (2017). A psychometric analysis of the Utrecht Work Engagement Scale in Indian banking sector. Ind. Commer. Train. 49, 296-302. doi: 10.1108/ICT-04-2017-0031

Le, H., Jiang, Z., and Nielsen, I. (2016). Cognitive cultural intelligence and life satisfaction of migrant workers: the roles of career engagement and social injustice. Soc. Indic. Res. doi: 10.1007/s11205-016-1393-3. [Epub ahead of print].

Limesurvey GmbH (2017). LimeSurvey: An Open Source Survey Tool [Computer Software]. Available online at: http://www.limesurvey.org

Littman-Ovadia, H., and Balducci, C. (2013). Psychometric properties of the Hebrew version of the Utrecht Work Engagement Scale (UWES-9). Eur. J. Psychol. Assess. 29, 58-63. doi: 10.1027/1015-5759/a000121
López, S. R. (2000). "Teaching culturally informed psychological assessment," in Handbook of Cross-Cultural and Multicultural Personality Assessment, ed R. H. Dana (Mahwah, NJ: Lawrence Erlbaum Associates), 669-687.

Lovakov, A. V., Agadullina, E. R., and Schaufeli, W. B. (2017). Psychometric properties of the Russian version of the Utrecht work engagement scale (UWES-9). Psychol. Russ. State Art 10, 145-162. doi: 10.11621/pir.2017.0111

Mäkikangas, A., Kinnunen, U., Feldt, T., and Schaufeli, W. B. (2016). The longitudinal development of employee well-being: a systematic review. Work Stress 30, 46-70. doi: 10.1080/02678373.2015.1126870

Marôco, J. (2014). Análise de Equações Estruturais: Fundamentos Teóricos, Software \& Aplicações, 2nd Edn. Pêro Pinheiro: ReportNumber.

Marques-Pinto, A., and Picado, L. (eds.). (2011). Adaptação e Bem-estar nas Escolas portuguesas: Dos Alunos aos Professores. Lisbon: Coisas de Ler.

Massey, D. S., and Tourangeau, R. (2013). Introduction: new challenges to social measurement. Ann. Am. Acad. Pol. Soc. Sci. 645, 6-22. doi: $10.1177 / 0002716212463314$

Matz-Costa, C. (2016). Productive aging in the workplace: Understanding factors that promote or impede subjective well-being at work. Best Pract. Ment. Health $12,43-62$.

Mauno, S., Kinnunen, U., and Ruokolainen, M. (2007). Job demands and resources as antecedents of work engagement: a longitudinal study. J. Vocat. Behav. 70, 149-171. doi: 10.1016/j.jvb.2006.09.002

McDonald, R. P., and Ho, M. H. (2002). Principles and practice in reporting structural equation analyses. Psychol. Methods 7, 64-82. doi: $10.1037 / 1082-989 X .7 .1 .64$

Meng, L., and Jin, Y. (2017). A confirmatory factor analysis of the utrecht work engagement scale for students in a Chinese sample. Nurse Educ. Today 49, 129-134. doi: 10.1016/j.nedt.2016.11.017

Mesurado, B., Richaud, M. C., and Mateo N. J. (2016). Engagement, flow, self-efficacy, and eustress of university students: a cross-national comparison Between the Philippines and Argentina. J. Psychol. 150, 281-299. doi: 10.1080/00223980.2015.1024595

Mills, M. J., Culbertson, S. S., and Fullagar, C. J. (2012). Conceptualizing and measuring engagement: an analysis of the Utrecht Work Engagement Scale. J. Happiness Stud. 13, 519-545. doi: 10.1007/s10902-011-9277-3

Millsap, R. E., and Yun-Tein, J. (2004). Assessing factorial invariance in ordered-categorical measures. Multivariate Behav. Res. 39, 479-515. doi: 10.1207/S15327906MBR3903_4

Mostert, K., Theron, B., and de Beer, L. T. (2017). Validating strengths use and deficit correction behaviour scales for South African first-year students. SA J. Ind. Psychol. 43, 1-12. doi: 10.4102/sajip.v43i0.1395

Muilenburg-Trevino, E. M. (2009). A Psychometric Study of Work Engagement in an American Sample. Available online at: https://pdfs.semanticscholar.org/ 7533/d1ca4b4091065055e4458be07ca7647ddf68.pdf

Navarro, D. (2015). Learning Statistics with R: A Tutorial for Psychology Students and Other Beginners (R package version 0.5). Available online at: https://cran.rproject.org/package $=$ lsr

Nerstad, C. G., Richardsen, A. M., and Martinussen, M. (2010). Factorial validity of the Utrecht Work Engagement Scale (UWES) across occupational groups in Norway. Scand. J. Psychol. 51, 326-333. doi: 10.1111/j.1467-9450.2009.00770.x OECD (2016). International Migration Outlook 2016. Paris: OECD.

Oliden, P. E., and Zumbo, B. D. (2008). Reliability coefficients for ordinal response scales. Psicothema 20, 896-901.

Panthee, B., Shimazu, A., and Kawakami, N. (2014). Validation of nepalese version of utrecht work engagement scale. J. Occup. Health 56, 421-429. doi: 10.1539/joh.14-0041-OA

Paradnike, K., and Bandzevičiene, R. (2015). Autonomy as a personal resource for students occupational well-being. Int. J. Psychol. A Biopsychosoc. Approach 17, 97-115. doi: 10.7220/2345-024X.17.6

Petrović, I. B., Vukelić, M., and Cizmić, S. (2017). Work engagement in Serbia: Psychometric properties of the Serbian version of the Utrecht Work Engagement Scale (UWES). Front. Psychol. 8:1799. doi: 10.3389/fpsyg.2017.01799

Picado, L., Marques-Pinto, A., and Lopes da Silva, A. (2008). "O papel dos esquemas precoces mal adaptativos na relação entre a ansiedade e o burnout/engagement dos professores portugueses do $1^{\circ}$ ciclo," in Burnout e Engagement em Contexto Organizacional. Estudos com Amostras Portuguesas, 
eds A. Marques Pinto and M. J. Chambel (Lisbon: Livros Horizonte), 167-198.

Pilati, M., Sheikh, H., Sperotti, F., and Tilly, C. (eds.). (2015). How Global Migration Changes the Workforce Diversity Equation. Newcastle upon Tyne: Cambridge Scholars Publishing.

Pittenger, L. M. (2015). Emotional and social competencies and perceptions of the interpersonal environment of an organization as related to the engagement of IT professionals. Front. Psychol. 6:623. doi: 10.3389/fpsyg.2015.00623

Pocnet, C., Antonietti, J. P., Massoudi, K., Györkös, C., Becker, J., de Bruin, G. P., et al. (2015). Influence of individual characteristics on work engagement and job stress in a sample of national and foreign workers in Switzerland. Swiss J. Psychol. 74, 17-27. doi: 10.1024/1421-0185/a000146

Portalanza Chavarría, C. A., Grueso Hinestroza, M. P., and Duque Oliva, E. J. (2017). Properties of the Utrecht Work Engagement Scale (UWESS 9): Exploratory analysis of students in Ecuador. Innovar 27, 145-156. doi: 10.15446/innovar.v27n64.62374

Presbitero, A. (2017). How do changes in human resource management practices influence employee engagement? A longitudinal study in a hotel chain in the Philippines. J. Hum. Resour. Hosp. Tour. 16, 56-70. doi: 10.1080/15332845.2016.1202061

Putnick, D. L., and Bornstein, M. H. (2016). Measurement invariance conventions and reporting: the state of the art and future directions for psychological research. Dev. Rev. 41, 71-90. doi: 10.1016/j.dr.2016.06.004

R Core Team (2017). R: A Language and Environment for Statistical Computing (version 3.4.2) [Computer Software]. Available online at: https://www.rproject.org/

Rastogi, A., Pati, S. P., Kumar, P., Dixit, J. K., Pradhan, S., Rastogi, A., et al. (2017). Investigation of Psychometric Properties of UWES-S (Student Engagement) and Its Relationship with Burnout and Life Satisfaction in the Indian Context. Indian Institute of Management Kozhikode. Available online at: https://econpapers. repec.org/RePEc:iik:wpaper:222 (Accessed November 10, 2017).

Raykov, T. (2001). Estimation of congeneric scale reliability using covariance structure analysis with nonlinear constraints. Br. J. Math. Stat. Psychol. 54, 315-323. doi: 10.1348/000711001159582

Reijseger, G., Peeters, M. C. W., Taris, T. W., and Schaufeli, W. B. (2017). From motivation to activation: why engaged workers are better performers. J. Bus. Psychol. 32, 117-130. doi: 10.1007/s10869-016-9435-z

Rodríguez-Montalbán, R., Martínez-Lugo, M., and Sánchez-Cardona, I. (2014). Análisis de las propiedades psicométricas de la Utrecht Work Engagement Scale en una muestra de trabajadores en Puerto Rico. Univ. Psychol. 13, 1255-1266. doi: 10.11144/Javeriana.UPSY13-4.appu

Römer, J. (2016). The Korean Utrecht Work Engagement Scale-Student (UWESS): A factor validation study. TPM Testing. Psychom. Methodol. Appl. Psychol. 23, 65-81. doi: 10.4473/TPM23.1.5

Rosseel, Y. (2012). lavaan: An R package for structural equation modeling. J. Stat. Softw. 48, 1-21. doi: 10.18637/jss.v048.i02

Salanova, M., Llorens, S., and Martínez, I. M. (2016). Aportaciones desde la psicología organizacional positiva para desarrollar organizaciones saludables y resilientes. Psychol. Pap. 37, 177-184.

Salanova, M., Schaufeli, W. B., Llorens, S., Peiró, J. M., and Grau, R. (2000). Desde el "burnout" al "engagement": ¿ ¿Una nueva perspectiva? [From burnout to engagement: a new perspective?]. Rev. Psicol. Del Trab. y las Organ. 16, 117-134.

Samaluk, B. (2016). Migrant workers' engagement with labour market intermediaries in Europe: symbolic power guiding transnational exchange. Work. Employ. Soc. 30, 455-471. doi: 10.1177/0950017015594968

Sánchez-Cardona, I., Rodríguez-Montalbán, R., Toro-Alfonso, J., and Moreno Velázquez, I. (2016). Psychometric properties of the Utrecht Work Engagement Scale-Student (UWES-S) in university students in Puerto Rico. Rev. Mex. Psicol. $33,121-134$

Satorra, A., and Bentler, P. M. (2001). A scaled difference chi-square test statistic for moment structure analysis. Psychometrika 66, 507-514. doi: 10.1007/BF02296192

Sattar, T., Ahmad, K., and Mahnaz, S. H. (2015). Role of human resource practices in employee performance and job satisfaction with mediating effect of employee engagement. Pak. Econ. Soc. Rev. 53, 81-96.

Sautier, L. P., Scherwath, A., Weis, J., Sarkar, S., Bosbach, M., Schendel, M., et al. (2015). Assessment of work engagement in patients with hematological malignancies: psychometric properties of the German version of the Utrecht Work Engagement Scale 9 (UWES-9). Rehabilitation 54, 310-316. doi: 10.1055/s-0035-1555912

Schaufeli, W. B. (2017). Work Engagement in Europe: Relations with National Economy, Governance, and Culture. Leuven: KU Leuven. Available online at: www.wilmarschaufeli.nl/publications/Schaufeli/472.pdf

Schaufeli, W. B., and Bakker, A. B. (2003). Utrecht Work Engagement Scale. Utrecht: Occupational Health Psychology Unit, Utrecht University.

Schaufeli, W. B., and Bakker, A. B. (2010). "Defining and measuring work engagement: bringing clarity to the concept," in Work Engagement: A Handbook of Essential Theory and Research, eds A. B. Bakker and M. P. Leiter (New York, NY: Psychology Press), 10-24.

Schaufeli, W. B., Bakker, A. B., and Salanova, M. (2006). The measurement of work engagement with a short questionnaire: a cross-national study. Educ. Psychol. Meas. 66, 701-716. doi: 10.1177/0013164405282471

Schaufeli, W. B., Martinez, I. M., Marques-Pinto, A., Salanova, M., and Bakker, A. B. (2002a). Burnout and engagement in university students: a cross-national study. J. Cross. Cult. Psychol. 33, 464-481. doi: 10.1177/0022022102033005003

Schaufeli, W. B., and Salanova, M. (2007). "Work engagement: An emerging psychological concept and its implications for organizations," in Managing social and Ethical Issues in Organizations, eds S. W. Gilliland, D. D. Steiner, and D. P. Skarlicki (Greenwich, CT: Information Age Publishing), 135-177.

Schaufeli, W. B., Salanova, M., González-Romá, V., and Bakker, A. B. (2002b). The measurement of engagement and burnout: a two sample confirmatory factor analytic approach. J. Vocat. Behav. 3, 71-92. doi: 10.1023/A:1015630930326

Schaufeli, W. B., Shimazu, A., Hakanen, J., Salanova, M., and De Witte, H. (2017). An ultra-short measure for work engagement. Eur. J. Psychol. Assess. 1-15. doi: 10.1027/1015-5759/a000430

Scorsolini-Comin, F., Fontaine, A. M. G. V., Koller, S. H., and Santos, M. A., dos (2013). From authentic happiness to well-being: the flourishing of positive psychology. Psicol. Reflexão Crítica 26, 663-670. doi: 10.1590/S0102-79722013000400006

SemTools Contributors (2016). semTools: Useful Tools for Structural Equation Modeling (R package version 0.4-14) [Computer software]. Available online at: https://cran.r-project.org/package=semTools

Seppälä, P., Mauno, S., Feldt, T., Hakanen, J. J., Kinnunen, U., Tolvanen, A., et al. (2009). The construct validity of the utrecht work engagement scale: multisample and longitudinal evidence. J. Happiness Stud. 10, 459-481. doi: 10.1007/s10902-008-9100-y

Serviço de Estrangeiros e Fronteiras (2016). Relatório de Imigração, Fronteiras e Asilo 2015. Oeiras: Serviço de Estrangeiros e Fronteiras. Available online at: http://sefstat.sef.pt/Docs/Rifa_2014.pdf

Shah, D. (2009). Healthy worker effect phenomenon. Indian J. Occup. Environ. Med. 13, 77-79. doi: 10.4103/0019-5278.55123

Shimazu, A., Schaufeli, W. B., Kosugi, S., Suzuki, A., Nashiwa, H., Kato, A., et al. (2008). Work engagement in Japan: validation of the Japanese version of the Utrecht work engagement scale. Appl. Psychol. 57, 510-523. doi: 10.1111/j.1464-0597.2008.00333.x

Shuck, B., Twyford, D., Reio, T. G., and Shuck, A. (2014). Human resource development practices and employee engagement: examining the connection with employee turnover intentions. Hum. Resour. Dev. Q. 25, 239-270. doi: 10.1002/hrdq. 21190

Simbula, S., Guglielmi, D., Schaufeli, W. B., and Depolo, M. (2013). An Italian validation of the Utrecht Work Engagement Scale: characterization of engaged groups in a sample of school teachers. Appl. Psychol. Bull. 61, 43-54.

Sinval, J., Marques-Pinto, A., Queirós, C., and Marôco, J. (2018). Work engagement among rescue workers: Psychometric properties of the Portuguese UWES. Front. Psychol. 8:2229. doi: 10.3389/fpsyg.2017.02229

Sonnentag, S. (2003). Recovery, work engagement, and proactive behavior: a new look at the interface between nonwork and work. J. Appl. Psychol. 88, 518-528. doi: 10.1037/0021-9010.88.3.518

Spontón, C., Medrano, L. A., Maffei, L., Spontón, M., and Castellano, E. (2012). Validation of the engagement questionnaire UWES for the population of workers of Córdoba, Argentina. Liberabit 18, 147-154.

Storm, K., and Rothmann, S. (2003). A psychometric analysis of the Utrecht Work Engagement Scale in the South African police service. SA J. Ind. Psychol. 29, 62-70. doi: 10.4102/sajip.v29i4.129 
Sulaiman, W. S. W., and Zahoni, N. A. (2016). Validation of the Utrecht Work Engagement Scale (UWES) in the Malaysian context. Int. J. Soc. Sci. Humanit. 6, 672-676. doi: 10.18178/ijssh.2016.6.9.730

RStudio Team (2017). RStudio: Integrated Development for $R$ (version 1.1.383) [Computer software]. Available online at: http://www.rstudio.com/

Torabinia, M., Mahmoudi, S., Dolatshahi, M., and Abyaz, M. R. (2017). Measuring engagement in nurses: the psychometric properties of the Persian version of Utrecht Work Engagement Scale. Med. J. Islam. Repub. Iran 31, 83-89. doi: $10.18869 /$ mjiri.31.15

Truss, C., Delbridge, R., Alfes, K., Shantz, A., and Soane, E. (eds.). (2014). Employee Engagement in Theory and Practice. London: Routledge.

Tsubakita, T., Shimazaki, K., Ito, H., and Kawazoe, N. (2017). Item response theory analysis of the Utrecht Work Engagement Scale for Students (UWES-S) using a sample of Japanese university and college students majoring medical science, nursing, and natural science. BMC Res. Notes 10, 1-5. doi: 10.1186/s13104-017-2839-7

Ulusoy, N., Mölders, C., Fischer, S., Bayur, H., Deveci, S., Demiral, Y., et al. (2016). A matter of psychological safety: commitment and mental health in Turkish immigrant employees in Germany. J. Cross. Cult. Psychol. 47, 626-645. doi: 10.1177/0022022115626513

Vallières, F., McAuliffe, E., Hyland, P., Galligan, M., and Ghee, A. (2017). Measuring work engagement among community health workers in Sierra Leone: Validating the Utrecht Work Engagement Scale. J. Work Organ. Psychol. 33, 41-46. doi: 10.1016/j.rpto.2016.12.001

van de Schoot, R., Schmidt, P., and De Beuckelaer, A. (eds.). (2015). Measurement Invariance. Lausanne: Frontiers Media.

van de Vijver, F. J. R. (2000). “The nature of bias," in Handbook of Cross-Cultural and Multicultural Personality Assessment, Personality and Clinical Psychology Series, ed R. H. Dana (Mahwah, NJ: Lawrence Erlbaum), 87-106.

van Veldhoven, M., and Peccei, R. (eds.). (2015). Well-Being and Performance at Work: The Role of Context. East Sussex: Psychology Press.

Vazquez, A. C. S., Magnan, E., dos, S., Pacico, J. C., Hutz, C. S., and Schaufeli, W. B. (2015). Adaptation and validation of the Brazilian version of the utrecht work engagement scale. Psico USF 20, 207-217. doi: 10.1590/1413-82712015200202

Viljevac, A., Cooper-Thomas, H. D., and Saks, A. M. (2012). An investigation into the validity of two measures of work engagement. Int. J. Hum. Resour. Manag. 23, 3692-3709. doi: 10.1080/09585192.2011.639542

Villavicencio-Ayub, E., Jurado Cárdenas, S., and Aguilar Villalobos, J. (2014). Adaptation of the UWES and OSI scales for Mexican workers. Psicol. Iberoam. 22, 6-15.

Villotti, P., Balducci, C., Zaniboni, S., Corbiere, M., and Fraccaroli, F. (2014). An analysis of work engagement among workers with mental disorders eecently integrated to work. J. Career Assess. 22, 18-27. doi: 10.1177/1069072713487500
Wefald, A. J., Mills, M. J., Smith, M. R., and Downey, R. G. (2012). A comparison of three job engagement measures: examining their factorial and criterion-related validity. Appl. Psychol. Heal. Well Being 4, 67-90. doi: 10.1111/j.1758-0854.2011.01059.x

Weigl, M., Hornung, S., Parker, S. K., Petru, R., Glaser, J., and Angerer, P. (2010). Work engagement accumulation of task, social, personal resources: a three-wave structural equation model. J. Vocat. Behav. 77, 140-153. doi: 10.1016/j.jvb.2010.03.002

Wojczewski, S., Pentz, S., Blacklock, C., Hoffmann, K., Peersman, W., Nkomazana, O., et al. (2015). African female physicians and nurses in the global Care Chain: qualitative explorations from five destination countries. PLOS ONE 10, 1-20. doi: 10.1371/journal.pone.0129464

Xanthopoulou, D., Bakker, A. B., Kantas, A., and Demerouti, E. (2012). Measuring burnout and work engagement: factor structure, invariance, and latent mean differences across Greece and the Netherlands. Int. J. Bus. Sci. Appl. Manag. 7, 40-52. doi: 10.1080/09585192.2012.751438

Yew, T. S., Sidek, M. Y., Jalil, R. A., and Arifin, W. N. (2017). Confirmatory factor analysis of the Malay version of Utrecht Work Engagement Scale (UWES-M). Int. J. Public Heal. Clin. Sci. 4, 77-86.

Yi-wen, Z., and Yi-qun, C. (2005). The Chinese version of utrecht work engagement scale: an examination of reliability and validity. Chin. J. Clin. Psychol. 13, 268-270. doi: 10.16128/j.cnki.1005-3611.2005. 03.005

Yusoff, R. B. M., Ali, A. M., Khan, A., and Bakar, S. A. (2013). Psychometric evaluation of Utrecht Work Engagement Scale among academic staff in universities of Pakistan. World Appl. Sci. J. 28, 1555-1560. doi: 10.5829/idosi.wasj.2013.28.11.2014

Zecca, G., Györkös, C., Becker, J., Massoudi, K., de Bruin, G. P., and Rossier, J. (2015). Validation of the french utrecht work engagement scale and its relationship with personality traits and impulsivity. Eur. Rev. Appl. Psychol. 65, 19-28. doi: 10.1016/j.erap.2014.10.003

Conflict of Interest Statement: The authors declare that the research was conducted in the absence of any commercial or financial relationships that could be construed as a potential conflict of interest.

Copyright (C) 2018 Sinval, Pasian, Queirós and Marôco. This is an open-access article distributed under the terms of the Creative Commons Attribution License (CC $B Y)$. The use, distribution or reproduction in other forums is permitted, provided the original author(s) and the copyright owner are credited and that the original publication in this journal is cited, in accordance with accepted academic practice. No use, distribution or reproduction is permitted which does not comply with these terms. 